\title{
PROSOPOGRAFIA FAMILIAR DA OPERAÇÃO "LAVA-JATO" E DO MINISTÉRIO TEMER $^{1}$
}

\author{
Ricardo Costa de Oliveira ${ }^{2}$ \\ José Marciano Monteiro ${ }^{3}$ \\ Mônica Helena Harrich Silva Goulart ${ }^{4}$ \\ Ana Crhistina Vanali ${ }^{5}$
}

\begin{abstract}
RESUMO: os autores apresentam a prosopografia dos principais operadores da "Lava-Jato" e a composição social, política e familiar do primeiro Ministério do Governo de Michel Temer. Analisou-se as relações familiares, as conexões entre estruturas de poder político, partidos políticos e estruturas de parentesco, formas de nepotismo, a reprodução familiar dos principais atores. Pesquisou-se a lógica familiar, as genealogias, as práticas sociais, políticas e o ethos familiar dentro das instituições políticas para entender de que maneira as origens sociais e familiares dos atores burocráticos, jurídicos e políticos formam um certo "habitus de classe", certa mentalidade política, uma cultura administrativa, uma visão social de mundo, padrões de carreiras e de atuações políticas relativamente homogêneos. As origens sociais, a formação escolar, acadêmica, as práticas profissionais, os cargos estatais, os privilégios e os estilos de vida, as ideologias e os valores políticos apresentam muitos elementos em comum nas biografias, e nas trajetórias sociais e políticas desses atores.
\end{abstract}

Palavras-chave: Lava-Jato. Ministério Temer. Prosopografia.

\section{FAMILY PROSOPHOGRAPHY OF THE "LAVA-JATO" OPERATION AND THE MINISTRY TEMER}

\begin{abstract}
The authors present the prosopography of the main operators of the "Lava-Jet" and the social, political and family composition of the first Ministry of Government of Michel Temer. Family relations, the connections between structures of political power, political parties and kinship structures, forms of nepotism, and family reproduction of the main actors were analyzed. Family logic, genealogies, social practices, politics and family ethos within political institutions were investigated to understand how the social and family origins of bureaucratic, juridical and political actors form a certain "class habitus", certain Political mentality, an administrative culture, a world view of the world, relatively homogeneous career patterns and political actions. Social origins, scholastic training, academic, professional practices, state offices, privileges and lifestyles, ideologies and political values present many elements in common in the biographies, and in the social and political trajectories of these actors.
\end{abstract}

Keywords: Lava-Jet. Temer's Ministry. Prosopography.

- Enviado em 15/07/2017

- Aprovado em 28/07/2017

\footnotetext{
${ }^{1}$ Uma versão preliminar desse texto foi apresentada no $18^{\circ}$ Congresso Brasileiro de Sociologia. Que Sociologia azemos? Interfaces com contextos locais, nacionais e globais realizado de 26 a 29 de julho de 2017 no Centro de Convenções Ulysses Guimarães, Brasília/DF.

${ }^{2}$ Professor de Sociologia na Universidade Federal do Paraná.

${ }^{3}$ Professor de Sociologia na Universidade Federal de Campina Grande-Paraíba.

${ }^{4}$ Professora de Sociologia na Universidade Tecnológica Federal do Paraná.

${ }^{5}$ Doutora em Sociologia e membro do grupo de estudos CNPq NEP (Núcleo de Estudos Paranaenses da UFPR).
} 


\section{Introdução}

O campo da justiça e o campo da política, assim como qualquer outro campo, se constituem a partir de processos de disputas. O campo da justiça no Brasil não pode ser compreendido sem a relação com o campo político. Assim, lançar o olhar analítico sobre a operação Lava-Jato e o Ministério Temer, permite situar, ainda que de forma introdutória, as posições que cada agente ocupa na operação e no ministério; e, mais que isso, permite observar as biografias e trajetórias, com especial destaque para a variável família, a origem social do agente e os espaços de formações pelas quais passaram. Este mapeamento, ainda que exploratório, nos possibilita pensar hipóteses que fortaleceram, ainda mais, a construção desta pesquisa, em curso, sobre a Operação Lava-Jato e o primeiro Ministério Temer.

Mapear a que família, genealogia, rede social e política pertencem os operadores da operação Lava-Jato e os ministros do primeiro Ministério Temer, as profissões, os currículos e atuação política dos agentes, pais e familiares. Identificar a escolaridade/formação, lugar de formação, trajetórias da vida profissional, lugares que frequentam, círculos de sociabilidades, padrões de matrimônios, cultura política, dentre outros elementos, permitem compreender a constituição das matrizes de percepções e valores, as formas pelas quais estes agentes classificam o mundo e que, muitas vezes, orientam suas escolhas e decisões. Os valores construídos desde a infância e reforçados nos espaços escolares, nos espaços de sociabilidades, em que frequentam também se transformam em objetos valiosos de análises para a compreensão de grupos seletos de indivíduos e sua relação com a condição de classe na qual ocupam posições no espaço da estrutura social. Permite-nos, portanto, problematizar no sentido de nos perguntarmos: até que ponto os agentes da operação Lava-Jato e do Ministério Temer operam a partir dos valores e percepções materializadas, incorporadas (muitas vezes inconscientes) e orientadas pela classe a qual pertencem? Quais as matrizes de percepções destes agentes, observando a condição e a posição de classe que ocupam na estrutura social? Quais suas trajetórias e em que espaços foram formados?

Não se pode compreender, portanto, a "elite da Lava-Jato" sem compreender a rede de relações sociais, profissionais, políticas e ideológicas que constituem estes agentes. Tais agentes não podem ser compreendidos dissociados de suas trajetórias e das trajetórias de seus familiares. Assim como não podem ser analisados de forma isolada, como indivíduos abstratos, que agem de acordo com o que "diz a lei”. São indivíduos concretos que possuem intenções e interesses em suas 
ações, além de pertencerem a famílias e classe sociais "privilegiadas", possuidoras de uma cosmovisão de mundo, que, em muito, foi construída no decorrer do processo histórico nas principais instituições que formaram e formam as elites jurídicas e as elites políticas do país. Estas são conectadas e atreladas às elites do dinheiro, que em sua totalidade formam, com a elite midiática, a classe dominante em nosso país. Este seleto grupo de indivíduos, os operadores da Lava-Jato e do Ministério Temer, forma parte do $1 \%$ mais rico no Brasil e muitos até mesmo do $0,1 \%$ mais rico em termos de rendas.

As instituições que formam os bacharéis em Direito geralmente apresentam uma visão de mundo tradicional e conservadora na reprodução das desigualdades sociais. Não tão diferente, e de forma significativa, os cursos de direito no Brasil possuem uma relação histórica direta na formação de quadros das elites para ocupar os principais cargos da alta burocracia estatal e os cargos eletivos no país. Embora tenha diminuído este padrão de recrutamento, por meio da proliferação dos cursos de direito, para os outros cargos eletivos da república, quando comparado a outros períodos da história; porém, não é de se afirmar que isto diminuiu para os cargos que exigem a expertise e monopólios na área para a atuação nas instituições que formam o sistema de justiça no Brasil.

Quase sempre as elites institucionais são compostas por juristas que ocupam cargos chave das instituições da administração da Justiça estatal, como o Supremo Tribunal Federal (STF), o Superior Tribunal de Justiça, os tribunais estaduais, o Ministério Público, a Ordem dos Advogados do Brasil (OAB) e o Conselho Nacional de Justiça (CNJ). E, conforme salienta Almeida (2010) as elites profissionais, por sua vez, são caracterizadas por lideranças corporativas dos grupos de profissionais do Direito que atuam na administração da Justiça estatal, como a Associação dos Magistrados Brasileiros, OAB e a Confederação Nacional do Ministério Público. As elites intelectuais são formadas por especialistas em temas relacionados à administração da Justiça estatal. Este grupo, apesar de não possuir uma posição formal de poder, tem influência nas discussões sobre o setor e em reformas políticas, como no caso dos especialistas em direito público e em direito processual.

Na pesquisa realizada por Almeida (2010) é possível identificar três elites políticas que têm em comum a origem social, as universidades e as trajetórias profissionais. Segundo Almeida (2010, p.38), todos os juristas que formam esses três grupos provêm da elite ou da classe média em ascensão e de faculdades de Direito tradicionais, como o Faculdade de Direito (FD) da USP, a Universidade Federal de Pernambuco e, em segundo plano, as Pontifícias Universidades Católicas 
(PUC's) e as Universidades Federais e Estaduais da década de 60. Ao lançarmos o olhar sobre a “elite” responsável pela operação Lava-Jato, veremos que sua formação tem vinculação, em termos de graduação, no Brasil e com especial destaque para as Universidades situadas no eixo sul-sudeste, com destaque a Universidade Federal do Paraná. Porém, em termos de pós-graduação, o núcleo duro da operação, realiza formação no Brasil e no exterior, com especial destaque para formações em universidades de língua inglesa.

Estas características são importantes para compreendermos as trajetórias e o habitus de classe deste seleto grupo e dos que formam o primeiro Ministério Temer, não menos importante é testar a hipótese de que tanto os membros da Lava-Jato e os membros do primeiro Ministério Temer possuem trajetórias que não podem ser entendidas sem relacioná-las a constituição de certas “dinastias do poder”, certas famílias presentes na elite estatal há mais de uma geração. Em relação à Lava-Jato com procuradores e policiais federais quase sempre advindos de famílias em que pais e familiares atuaram e/ou atuam no sistema de justiça, muitos no período da última ditadura militar, portanto, pertencentes, a certa "dinastia jurídica". No que tange ao primeiro Ministério Temer, observa-se que, parte significativa dos agentes nomeados para ocupar as pastas, advém de tradicionais famílias políticas e mesmo de "dinastias políticas". O teste positivo de tal hipótese de investigação permite-nos compreender como estas "dinastias jurídicas" e "dinastias políticas", em boa parte formadas pela hereditariedade, agem no aparelho de Estado de forma a entender o habitus constitutivo destes agentes pertencentes à classe dominante do país.

Em outras palavras, a partir do método prosopográfico, é possível identificar, através da biografia, formação, trajetória profissional e cargos ocupados, como famílias presentes por várias gerações no cenário jurídico e no cenário político, conseguem se manter, organizar relações e ativamente se reproduzir ao longo de séculos em nosso país. Permite, ainda, perceber como agentes de uma operação como a "Lava-Jato", agem de acordo com interesses construídos no decorrer de sua formação, o que possibilita em certo sentido desmistificar "o mito das decisões neutras" e de um sistema de justiça que atua em consonância com o "princípio da imparcialidade”. É neste sentido que Almeida (2010) chama a atenção para o peso do "sobrenome de famílias" de juristas como variável que no Brasil tem importado para as escolhas de cargos-chave nas altas cortes, no STJ, por exemplo. O que demonstra o quanto o sistema de justiça e, mais especificamente, os poderes que constituem o judiciário são atravessados por disputas e interesses de classes, no sentido de disputa política pelo controle da administração do sistema Judiciário no Brasil. "No STF, sete dos 11 ministros têm parentes como donos, administradores ou funcionários de grandes escritórios 
de advocacia, aponta levantamento do site Poder 360. Um oitavo, novamente o ministro Fux, tinha uma filha advogada que trabalhava em grande escritório até o ano passado, quando ela deixou o posto para virar desembargadora no Tribunal de Justiça do Rio de Janeiro — sob questionamento formal de que não tinha qualificações para tanto e suspeitas de influência de seu pai na nomeação. Assim, esse tipo de suspeita está disseminada por praticamente todos os níveis do Judiciário nacional. ${ }^{6,}$

Nesse sentido, e diante do exposto, o objetivo geral desta pesquisa é o estudo prosopográfico dos membros da Operação Lava-Jato para a identificação do perfil genealógico dos operadores, seus vínculos familiares, sociais e institucionais. Assim poderemos traçar padrões na carreira desses operadores e caracterizar que tipo de influência política exercem. Em termos metodológicos, o método utilizado é o prosopográfico, posto que se tratam de biografias coletivas, de forma quantitativa, visando dar o sentido às ações políticas do grupo pesquisado (STONE, 2011).

O ambiente do grupo investigado em suas instituições, educação, preferências políticas, habitus de classe, estilos sociais, relações sociais e políticas. A prosopografia é idealmente adequada para revelar as redes de profundos vínculos sociopsicológicos que mantêm um grupo unido. Este método prosopográfico funciona melhor quando é aplicado para grupos facilmente definidos e razoavelmente homogêneos em suas características sociais e políticas, quando os dados são obtidos de uma grande variedade de fontes, que complementam e enriquecem umas às outras. Metodologia quantitativa e qualitativa, operacionalização da técnica de pesquisa genealógica e análise das trajetórias familiares e carreiras profissionais.

O universo da pesquisa compreende, portanto, os membros dos três núcleos principais Operação Lava-Jato - 14 procuradores do Ministério Público Federal, 8 delegados da Polícia Federal, o juiz Sérgio Moro e o Procurador Geral da República Rodrigo Janot Monteiro de Barros. O propósito desta prosopografia é dar sentido à ação política da Operação Lava-Jato e compreender a "força coesiva do grupo" pelas suas opções, relações, posicionamento, filiações econômicas, ideológicas e políticas dos seus membros. Soma-se a isso também a prosopografia dos Ministros nomeados primeiramente para compor o Ministério Temer, após o Golpe institucional em abril de 2016. Pesquisas sobre a prosopografia dos operadores da Lava-Jato revelam quem são, como pensam e agem no campo político. Ao traçar uma radiografia desse grupo social, por meio de

\footnotetext{
${ }^{6}$ BORGES, Rodolfo (26/05/2017). Os laços da grande família jurídica do Brasil voltam à tona com a Lava-Jato.
} Disponível em htttp://brasil.elpais.com/brasil/2017/05/15/politica/1494855502 654494.html. Acesso 18.junho.2017. 
biografia coletiva e da construção de seu perfil, será possível entender as raízes sociais de suas ações e a quem representam.

\section{O que é a força-tarefa da Operação Lava-Jato?}

A Operação Lava-Jato é atualmente o epicentro da crise política que se vive no Brasil. Sua investigação começou pelas grandes empreiteiras e sua relação de natureza corrupta com altos quadros da Petrobrás no sentido de terem favorecimentos na obtenção de contratos públicos. Com isso, ela foi saudada como uma esperança de enfrentamento da corrupção no país, haja vista que, pela primeira vez, estava se colocando em primeiro plano do processo de investigação as grandes empresas corruptoras.

Em 17 de março de 2014, a Polícia Federal realizou prisões temporárias e preventivas de 17 pessoas em sete estados, entre elas o doleiro Alberto Youssef ${ }^{7}$. Três dias depois, em 20 de março de 2014, a Polícia Federal cumpriu 6 mandados de busca e 1 de prisão temporária, a de Paulo Roberto Costa, ex-diretor da Petrobrás. Em sua sétima fase, batizada de "Juízo Final", a Polícia Federal cumpriu 49 mandados de busca, 6 de prisão preventiva e 21 de prisão temporária, sendo presos os presidentes e diretores de grandes empresas do Brasil, como Construtora OAS, IESA Óleo \& Gás, Camargo Corrêa Construções, UTC Engenharia, Engevix e Construtora Queiroz e Galvão.

Em 19 de junho de 2015, na décima quarta fase da Operação, a Polícia Federal deflagrou a fase da Operação Lava-Jato, com nome "Erga Omnes", expressão em latim que significa "vale para todos". Os alvos foram às empreiteiras Odebrecht e Andrade Gutierrez. Foram presos na operação os presidentes da Odebrecht, Marcelo Odebrecht e da Andrade Gutierrez, Otávio Azevedo. Também foram presos os diretores da Odebrecht Márcio Faria, Rogério Araújo e Alexandrino Alencar. Desta forma, a Operação Lava-Jato colocava no centro às relações mercantis entre os

\footnotetext{
${ }^{7}$ Alberto Youssef foi condenado em 2004, pelo mesmo juiz Sérgio Moro, do Paraná, por corrupção no caso Banestado. Segundo a Ação Penal movida contra Youssef, ele obteve um empréstimo de US\$ 1,5 milhão, em 1998, numa agência do Banestado, banco público do Paraná, nas Ilhas Cayman. No processo de delação premiada da época, Youssef confessou que internou o dinheiro no Brasil de forma ilegal, ao invés de fazê-lo via Banco Central. Segundo o doleiro, a condição imposta para o Banestado liberar o dinheiro para sua empresa, a Jabur Toyopar, era fazer uma doação para a campanha de Jaime Lerner, do então, aliado do PSDB, para o governo do Paraná. Alberto Youssef operava para políticos do PFL, PP e PSDB do Paraná desde a primeira eleição de Jaime Lerner, em 1994. Assim como operou também para FHC e Serra em 1994 e 1998. Consultar "Moro e Youssef: personagens de uma longa história". Disponível em http://www.diariodocentrodomundo.com.br/moro-e-youssef-personagens-de-uma-longa-historia/. Acesso 13.maio.2017.
} 
grandes lobbies de interesses privados e o processo de eleições no Brasil, o trânsito e a organização de redes de corrupção através do financiamento empresarial de eleições e partidos.

A legitimidade da Lava-Jato estaria calcada no lema "vale para todos". Entretanto, com o decorrer da Operação Lava-Jato, tornou-se evidente que o foco era não para desmantelar o sistema privado de corrupção sobre o Estado, em grande medida herdada da ditadura civil-militar, mas para inviabilizar o governo Dilma, o PT e perseguir e desmoralizar o ex-presidente Lula. O que minou as expectativas de que a Lava-Jato pudesse focar na estrutura do sistema político foi à forma seletiva como o juiz Sérgio Moro, os procuradores e policiais federais envolvidos na Operação escolheram os alvos políticos dela.

Uma das principais referências para compreender a ação política da força-tarefa é o trabalho “Manual de Atuação das Forças-Tarefas", publicado pela Escola Superior do Ministério Público da União em 2011. Este trabalho foi coordenado por Januário Paludo e preparado por Carlos Fernando - ambos na Lava-Jato - e pelo secretário de cooperação internacional da Procuradoria Geral da República, Vladimir Aras. O manual das forças-tarefas inspira-se principalmente na experiência dos Estados Unidos. Aponta que "segundo o Agente Especial do FBI James Casey, o elemento crítico de uma força-tarefa é a sua composição. É essencial que existam membros com diferentes habilidades e um acompanhamento constante das atividades do grupo, com coordenação administrativa e operacional, levantamento estatístico e verificação de resultados" (PALUDO, 2011, p.32). Neste sentido, a análise dos operadores da Lava-Jato deve nos revelar quem são, como pensam e agem no campo político. Ao traçar uma radiografia desse grupo social, por meio de sua biografia coletiva e da construção de seu perfil, será possível identificar as raízes sociais de suas ações.

A força-tarefa da Lava-Jato compreende cerca de 22 membros. O juiz titular Sérgio Fernando Moro da primeira instância da Justiça Federal do Paraná. Os 14 membros designado pelo procurador-geral da República, Rodrigo Janot, pelo Ministério Público: Deltan Martinazzo Dallagnol (coordenador), Antônio Carlos Welter, Carlos Fernando dos Santos Lima, Januário Paludo, Orlando Martello Junior, Athayde Ribeiro Costa, Diogo Castor de Mattos, Roberson Henrique Pozzobon, Paulo Roberto Galvão de Carvalho, Júlio Carlos Motta Noronha, Jerusa Burmann Viecili, Isabel Cristina Groba Vieira, Laura Gonçalves Tessler e Andrey Borges de Mendonça já integrou a equipe e atua como colaborador. E 8 (oito) delegados da Polícia Federal: 


\section{Marcio Adriano Anselmo, Igor Romário de Paula, Erika Mialik Marena, Eduardo Mauat da Silva, Renata Rodrigues, Luciano Flores, Ivan Ziolkowki e Felipe Hayashi.}

Muitos dos personagens da Lava-Jato remetem a investigação relacionada ao caso Banestado, esquema pelo qual mais de 28 bilhões de dólares foram remetidos ilegalmente ao exterior e que embora a investigação tenha sido iniciada em 2003, não surtiu tantos efeitos como esperado. No caso Banestado encontra-se o juiz Sérgio Moro. Este que foi o responsável pelo julgamento do caso. No Ministério Público Federal (MPF), os responsáveis pelas investigações foram os procuradores Carlos Lima, Januário Paludo e Orlando Martello Junior, que também integram a força tarefa do órgão que investiga os crimes cometidos no âmbito da Lava-Jato. Um dos réus da Lava-Jato, inclusive, também foi o personagem central do escândalo do Banestado: Alberto Youssef. Este que conseguiu não responder pelos crimes de corrupção ativa e de participação em gestão fraudulenta de instituição financeira (Banestado), por acordo, com MPF de delação premiada, em 2004. Da Polícia Federal, Marcio Anselmo e Érika Mialik também trabalharam nas investigações no caso.

\section{"Prosopografia da Lava-Jato"}

Sérgio Fernando Moro é descendente de imigrantes italianos, filho de Odete Starke Moro e Dalton Áureo Moro (1934-2005). O casal se mudou para Maringá no final da década de 1960, a convite de um cunhado dela, Neumar Godoy, fundador e reitor da Universidade Estadual de Maringá (UEM) - criada no primeiro ato do coronel Jarbas Passarinho como ministro da Educação do general Emílio Médici, em 6 de novembro de 1969. Os dois começaram no Colégio Estadual Gastão Vidigal, ele lecionando geografia e ela português. O colégio se tornaria o embrião da UEM, da qual Dalton foi um dos fundadores.

Dalton $^{8}$ é filho de Lavino Nadal Moro e Áurea Godoy Moro. Cursou o ensino primário no Grupo Escolar Senador Correia, o ginasial no Colégio Estadual Regente Feijó e o ensino médio na Escola Técnica Estadual de Comércio. Foi aluno da primeira turma de Licenciatura em Geografia na antiga Faculdade de Filosofia, Ciências e Letras de Ponta Grossa/PR, no período de 1963 a 1966. Como integrante do ensino superior, foi presidente do Diretório Acadêmico Dr. Joaquim de Paula

\footnotetext{
${ }^{8}$ Homenagem a Dalton Moro. Disponível em http://revista.fct.unesp.br/index.php/formacao/article/viewFile/676/700. Acesso 18.junho.2017.
} 
Xavier, entidade que congregava os acadêmicos das licenciaturas, quando foi agraciado com uma viagem de estudos aos Estados Unidos. Em 1968 tornou-se professor do ensino superior ao ser aprovado em concurso público para o curso de Geografia - Geografia Regional - da recém-fundada Faculdade de Filosofia, Ciências e Letras, uma das unidades de ensino superior que deram origem à Universidade Estadual de Maringá. De 1974 a 1980 fez o curso de mestrado na Universidade de São Paulo (USP), sob a orientação do Prof. Dr. Manoel Fernando Gonçalves Seabra. De 1989 a 1992 cursou o doutorado no Instituto de Geociências e Ciências Exatas da Universidade Estadual Paulista- UNESP, campus de Rio Claro, tendo como orientadora a Profa. Dra Lúcia Helena de Oliveira Gerardi.

Em julho de 1968 Dalton casou-se com Odete Starke Moro com quem teve dois filhos. Sérgio Moro nasceu em Maringá, em $1^{\text {o }}$ de agosto de 1972, "seguiu os passos do pai ${ }^{9}$ e integrou o mesmo Departamento de Geografia da UEM" e também deu aula nos colégios Papa João XIII e Dr. Gastão Vidigal. Em 1990 inicia o curso de Direito na Universidade Estadual de Maringá, concluindo-o em 1995. Trabalhou para o advogado Irinaldo Joaquim de Souza. É Mestre e Doutor em Direito pela Universidade Federal do Paraná. Tornou-se juiz federal em 1996. Cursou o programa para instrução de advogados da Harvard Law School em 1998 e participou de programas de estudos sobre lavagem de dinheiro promovidos pelo Departamento de Estado dos Estados Unidos. Atualmente é juiz federal da $13 .^{a}$ Vara Criminal Federal de Curitiba, ministra aulas de processo penal na Universidade Federal do Paraná (UFPR). No caso do "Mensalão", a ministra do Supremo Tribunal Federal (STF) Rosa Weber convocou o juiz Sérgio Moro para auxiliá-la. Ela se notabilizou ao condenar José Dirceu com as seguintes palavras: "não tenho prova cabal contra Dirceu, mas vou condená-lo porque a literatura jurídica me permite". Depois Moro ganhou notoriedade internacional por comandar o julgamento dos crimes identificados na Operação LavaJato.

Sérgio Moro é casado com Rosângela Wolff de Quadros. Rosângela se graduou na Faculdade de Direito de Curitiba entre 1992 e 1996 e fez pós-graduação em direito tributário na Universidade de Joinville. Fez parte do escritório de Advocacia Zucolotto Associados em Maringá. O escritório defende várias empresas petrolíferas estrangeiras. Rosangela Maria Wolff de Quadros, advogada, procuradora jurídica da Federação Nacional das APAES e da APAE-PR ${ }^{10}$. A genealogia

\footnotetext{
${ }^{9}$ Disponível em http://istoe.com.br/397390_SERGIO+MORO/. Acesso 18.junho.2017.

${ }^{10}$ Disponível em https://apaebrasil.org.br/noticia/doutora-rosangela-moro-assume-a-procuradoria-juridica-da-feapaespr. Acesso 18.junho.2017.
} 
política básica de Rosangela Maria Wolff de Quadros Moro a insere na grande família do poder Centro Cívico de Curitiba. A classe dominante do Paraná tradicional é uma grande estrutura de parentesco, quase sempre com as mesmas famílias da elite estatal ocupando simultaneamente os poderes executivo, legislativo e judiciário. Rosângela Moro é prima do prefeito Rafael Greca de Macedo $^{11}$. Ambos descendem do Capitão Manoel Ribeiro de Macedo, preso pelo primeiro Presidente da Província do Paraná por acusações de corrupção e desvio de bens públicos em instalações estatais. No livro sobre a genealogia da família Macedo assim são descritos:

Existem vários homens e mulheres de grande valor em nossa família, não podemos citar seus nomes, pois seriam muitos, certamente omitiríamos alguns. Tivemos parentes na Interventoria, no Governo do Estado, na Política Estadual e Federal, no Tribunal de Justiça, Tribunal de Alçada, Tribunal de Contas, Assembleia Legislativa, Prefeituras de diversos Municípios, Reitoria, Universidade Federal do Paraná, nas Secretarias do Estado, no Magistério Público, no antigo Tesouro do Estado, nas Funções Pùblicas e Privadas, na Indústria e no Comércio, sempre honrando o nome da família. Só para lembrar: Nestes 108 anos de Associação Comercial do Paraná, 37 foram presididos por pessoas descendentes ou ligados diretamente à Família de Manoel Ribeiro de Maced. (MACEDO, 1998, p.24)

A grande teia de nepotismo e familismo explica muito do atraso, falta de justiça e desigualdades no Paraná e Curitiba, locais em que famílias com mentalidades políticas do "Antigo Regime" ainda mandam e dominam. Moro e Wolff são famílias de origem imigrante, que conseguiram entrar para o poder judiciário, famílias com parentes desembargadores, do lado Wolff os desembargadores Haroldo Bernardo da Silva Wolff e Fernando Paulino da Silva Wolff Filho, do lado da família Moro o desembargador Hildebrando Moro. Outro parente influente de Rosângela é Luiz Fernando Wolff de Carvalho, do grupo Triunfo, bastante ativo nas atividades empresariais e na política regional, sempre envolvido com problemas jurídicos. A família Wolff dominou por muitos anos a prefeitura de São Mateus do Sul, no interior do Paraná. Essas famílias de origem imigrante passaram a formar parte do estamento burocrático com seus privilégios e poderes, muitas vezes se associando na grande e antiga teia de nepotismo, de escravidão, exclusão social e coronelismo das antigas e sempre atuais oligarquias familiares da classe dominante paranaense.

Rosangela Woff Moro assumiu a Procuradoria Jurídica da Federação Nacional das APAES desde $2013^{12}$. O Secretário Para Assuntos Estratégicos do Paraná Flávio José Arns há muitos anos

\footnotetext{
${ }^{11}$ Consultar Macedo (1998, p.51).

12 Disponível em https://apaebrasil.org.br/noticia/doutora-rosangela-moro-assume-a-procuradoria-juridica-da-feapaespr. Acesso 18.junho.2017
} 
apresenta atuação política na área das APAES. O sobrinho de Flávio Arns, Marlus Arns de Oliveira também atuou juridicamente nessa área. Marlus Arns também foi advogado do ex-Deputado Eduardo Cunha e de sua mulher Cláudia Cruz, além de Renato Duque ${ }^{13}$, o que revela uma lucrativa “indústria advocatícia da Lava-Jato”, com redes sociais e políticas operando em sintonia. Também atua na clientela da Lava-Jato o irmão do procurador Diogo Castor de Mattos, Rodrigo Castor de Mattos $^{14}$, advogado do marqueteiro João Santana.

Carlos Fernando dos Santos Lima. É considerado o estrategista da investigação. Estudou no Colégio Santa Maria. Graduou-se na Faculdade de Direito Curitiba. Entre 1978 e 1991 foi Escriturário do Banco do Brasil. Foi Promotor de Justiça do MP-PR entre 1991 e 1995. Desde então é Procurador Regional da República. Foi membro da força-tarefa Banestado. Fez Mestrado na Cornell Law School entre 2008 e 2009. O procurador Carlos Fernando dos Santos Lima é filho do deputado estadual da ARENA Osvaldo dos Santos Lima, promotor, vice-prefeito em Apucarana e presidente da Assembleia Legislativa do Paraná, em 1973, no auge da ditadura, quando as pessoas não podiam votar e nem debater livremente. O avô foi Luiz dos Santos Lima, comerciante e juiz em São Mateus do Sul, na época do coronelismo local. A partir daí encontramos esta família na Genealogia Paranaense (V1, 543 e V4, 437) situada nas oligarquias da Lapa entre latifundiários escravistas, família aparentada ao Barão dos Campos Gerais e outros membros da classe dominante tradicional desta região. A Lapa já forneceu Flávio Suplicy de Lacerda, ministro da educação autoritário na ditadura militar e Ney Braga.

Carlos foi casado com Vera Márcia, ex-funcionária do Banco Banestado. A CPI que investigou o caso Banestado recebeu à época documentos provando que, entre 1995 e 2001, a então mulher do procurador, Vera Márcia Ribas de Macedo dos Santos Lima, trabalhava no Banestado e que, durante parte desse período, Carlos Fernando já atuava na investigação do esquema. Mais que isso, consta que sua mulher trabalhou em dois dos principais locais onde funcionava a "lavanderia"

\footnotetext{
13 Disponível em http://www1.folha.uol.com.br/poder/2015/08/1666311-advogado-desponta-na-lava-jato-comdelacoes.shtml?cmpid=comptw. Acesso 18.junho.2017.

${ }^{14}$ Disponível em http://painel.blogfolha.uol.com.br/2017/05/13/irmao-de-procurador-da-lava-jato-atua-como-advogadode-defesa-do-marqueteiro-joao-santana/. Acesso em 18.junho.2017.
} 
no Banestado e que, antes de o caso vir à tona, o procurador chegou a negar na CPI que algum parente trabalhasse no banco. Conforme a Revista Istó ${ }^{15}$ :

\begin{abstract}
Em sua ficha funcional, consta que Vera Márcia trabalhou em dois dos principais locais onde funcionava a lavanderia no Banestado. De acordo com os documentos, entre 1995 e 1997, quando ocorreu a maior parte das remessas irregulares para o Exterior, Vera Márcia, ainda casada com Santos Lima, trabalhava como escriturária no setor de abertura de contas da agência da Ponte da Amizade, em Foz de Iguaçu. A investigação da Polícia Federal sobre a evasão de divisas por intermédio do banco mostra que a maioria das contas de laranjas, usadas para mandar o dinheiro para o Exterior, foi aberta exatamente nessa agência. Em 1997, ao se mudar com o então marido para Curitiba, Vera Márcia caiu em um setor ainda mais estratégico da lavanderia: o Departamento de Operações Internacionais do Banestado, onde eram fechadas transações fraudulentas de câmbio. $O$ funcionamento da área de câmbio foi relatado por ex-gerentes do banco em depoimentos à CPI da Assembleia Legislativa de Curitiba, que também investiga o escândalo. Segundo os ex-gerentes, os funcionários desse setor recebiam comissão para recrutar doleiros $e$ pessoas interessadas em enviar recursos para o Exterior. Ainda de acordo com sua ficha funcional, Vera Márcia trabalhou no local até 2001.
\end{abstract}

Família de procuradores. Na posse do irmão Paulo Ovídio dos Santos Lima como Procurador de Justiça no MP-PR, em 2015: "A cerimônia de posse foi presidida pelo procuradorgeral de Justiça, Gilberto Giacoia, que destacou a história da família Santos Lima: o pai Osvaldo (em memória) e o irmão Luiz José foram procuradores de Justiça do MP-PR, e o irmão Carlos Fernando é procurador da República e atua na força-tarefa da Lava-Jato, do MPF"16.

O triunvirato de comando da Lava-Jato se completa com o procurador Deltan Dallagnol. Nascido em Pato Branco, Paraná, em 1980, é filho do procurador de justiça Agenor Dallagnol. Membro da igreja Batista. Tal como nos outros dois casos verificamos uma reprodução dentro da elite estatal, com os filhos preservando muitas vezes os valores e as ideologias dos pais na década de 70, época de autoritarismo e justiça de exceção. A mentalidade colonizada, subalterna e entreguista persiste ${ }^{17}$.

\footnotetext{
${ }^{15}$ Disponível em http://istoe.com.br/13447_AS+PROVAS/. Acesso 18.junho.2017.

${ }^{16}$ Disponível em http://www.diarioinduscom.com/mppr-ministerio-publico-do-parana-tem-novo-procurador-de-justica/. Acesso 18.junho.2017.

17 Disponível em https://www.brasil247.com/pt/247/brasil/256934/Dallagnol-atribui-corrup\%C3\%A7\%C3\%A3o\%C3\%A0-coloniza\%C3\%A7\%C3\%A3o-portuguesa.htm. Acesso 18.junho.2017.
} 


\section{PROSOPOGRAFIA DOS MEMBROS OPERAÇÃO LAVA-JATO}

\begin{tabular}{|c|c|c|c|c|c|}
\hline NOME & $\begin{array}{l}\text { LAVA- } \\
\text { JATO }\end{array}$ & $\begin{array}{l}\text { LOCAL/ } \\
\text { DATA } \\
\text { DE } \\
\text { NASCIM } \\
\text { ENTO }\end{array}$ & FORMAÇÃO & CARGOS QUE ATUOU & $\begin{array}{l}\text { REDE E ESTRUTURA } \\
\text { FAMILIAR }\end{array}$ \\
\hline $\begin{array}{l}\text { Sérgio } \\
\text { Fernando } \\
\text { Moro }\end{array}$ & $\begin{array}{l}\text { Juiz } \\
\text { Titular }\end{array}$ & $\begin{array}{l}\text { Maringá } \\
1972\end{array}$ & $\begin{array}{l}\text { Direito - Graduação na UEM } \\
\text { e Doutorado na UFPR }\end{array}$ & $\begin{array}{l}\text { Juiz e professor } \\
\text { universitário na UFPR }\end{array}$ & $\begin{array}{l}\text { Parente do desembargador } \\
\text { Hildebrando Moro - TJ-PR. } \\
\text { Marido da advogada } \\
\text { Rosangela Maria Wolff de } \\
\text { Quadros, parente da família } \\
\text { ou oligarquia política } \\
\text { Macedo do Paraná. } \\
\text { Rosângela também é parente } \\
\text { dos Desembargadores do TJ- } \\
\text { PR Haroldo Bernardo da } \\
\text { Silva Wolff e Fernando } \\
\text { Paulino da Silva Wolff } \\
\text { Filho, }\end{array}$ \\
\hline $\begin{array}{l}\text { Rodrigo } \\
\text { Janot } \\
\text { Monteiro de } \\
\text { Barros }\end{array}$ & $\begin{array}{l}\text { Ministério } \\
\text { Público } \\
\text { Procurado } \\
\text { r-geral da } \\
\text { República }\end{array}$ & $\begin{array}{l}\text { Belo } \\
\text { Horizont } \\
\text { e } \\
15 \text { de } \\
\text { setembro } \\
\text { de } 1956\end{array}$ & $\begin{array}{l}\text { Direito pela Universidade } \\
\text { Federal de Minas Gerais }\end{array}$ & $\begin{array}{l}\text { MPF } \\
\text { Procurador-Geral da } \\
\text { República do Brasil, desde } \\
2013 \text {. }\end{array}$ & $\begin{array}{l}\text { Família Histórica Monteiro } \\
\text { de Barros. Família do } \\
\text { Visconde de Congonhas, } \\
\text { Ministro da Justiça no } \\
\text { Império. } \\
\text { irmão Rogério Janot } \\
\text { Monteiro de Barros. } \\
\text { Filha do PGR Rodrigo Janot, } \\
\text { Letícia Ladeira Monteiro de } \\
\text { Barros é uma jovem } \\
\text { advogada, especializada em } \\
\text { direito econômico, que } \\
\text { trabalha em um escritório de } \\
\text { advocacia com relevantes } \\
\text { contas: Petrobrás, OAS e } \\
\text { Brasken. }\end{array}$ \\
\hline $\begin{array}{l}\text { Deltan } \\
\text { Martinazzo } \\
\text { Dallagnol }\end{array}$ & $\begin{array}{l}\text { Ministério } \\
\text { Público } \\
\text { Coordena } \\
\text { dor. E } \\
\text { Procurado } \\
\mathrm{r} \text { da } \\
\text { República }\end{array}$ & $\begin{array}{l}\text { Pato } \\
\text { Branco - } \\
\text { PR } \\
29 \text { de } \\
\text { janeiro } \\
\text { de } 1980 .\end{array}$ & $\begin{array}{l}\text { Formado em Direito pela } \\
\text { Universidade Federal do } \\
\text { Paraná. Mestre em Direito por } \\
\text { Harvard. }\end{array}$ & $\begin{array}{l}\text { Procurador do MPF desde } \\
2003 . \\
\text { Protestante da Igreja Batista. }\end{array}$ & $\begin{array}{l}\text { Filho do procurador de } \\
\text { justiça Agenor Dallagnol. }\end{array}$ \\
\hline $\begin{array}{l}\text { Andrey } \\
\text { Borges de } \\
\text { Mendonça }\end{array}$ & $\begin{array}{l}\text { Ministéri } \\
\text { o } \\
\text { Público } \\
\text { Procurad } \\
\text { or da } \\
\text { Repúblic } \\
\text { a }\end{array}$ & $\begin{array}{l}\text { Franca/ } \\
\text { SP }\end{array}$ & $\begin{array}{l}\text { Graduado em Direito pela } \\
\text { Universidade de São Paulo } \\
\text { (2001) e mestrado em Curso } \\
\text { de Direitos Humanos, } \\
\text { Interculturalidade pela } \\
\text { Universidade Pablo de } \\
\text { Olavide (2010). Atualmente é } \\
\text { professor da Escola Superior } \\
\text { do Ministério Público da } \\
\text { União. Membro do Instituto } \\
\text { ASF de Estudos Avançados. } \\
\text { Coordenador Adjunto do X } \\
\text { Curso de Ingresso e e }\end{array}$ & $\begin{array}{l}\text { Em 2004 passou no } \\
\text { concurso do MPF. Começou } \\
\text { a trabalhar em Campinas, } \\
\text { depois em Ribeirão Preto e } \\
\text { Santos. Desde 2013, está em } \\
\text { São Paulo, na Vara } \\
\text { Especializada em Crimes } \\
\text { contra o Sistema Financeiro } \\
\text { e Lavagem de Capitais. } \\
\text { Integrou Força Tarefa da } \\
\text { Lava-Jato em 2014 (durante }\end{array}$ & $\begin{array}{l}\text { É irmão do promotor Yuri } \\
\text { Borges de Mendonça, } \\
\text { integrante do Gaeco. }\end{array}$ \\
\hline
\end{tabular}




\begin{tabular}{|c|c|c|c|c|}
\hline & & $\begin{array}{l}\text { Vitaliciamento } \\
\text { Procuradores da República. É } \\
\text { Procurador da República do } \\
\text { Ministério Público Federal } \\
\text { desde 2004. É mestre, em } \\
\text { processo penal, pela } \\
\text { Universidade de São Paulo } \\
(2015) \text {. }\end{array}$ & 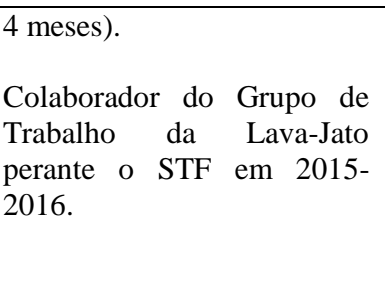 & \\
\hline $\begin{array}{l}\text { Antônio } \\
\text { Carlos } \\
\text { Welter }\end{array}$ & $\begin{array}{l}\text { Ministéri } \\
\text { o } \\
\text { Público } \\
\text { Procurad } \\
\text { or da } \\
\text { repúblic } \\
\text { a }\end{array}$ & $\begin{array}{l}\text { Bacharel em Ciências } \\
\text { Jurídicas e Sociais pela } \\
\text { Universidade Federal do Rio } \\
\text { Grande do Sul. }\end{array}$ & & \\
\hline $\begin{array}{l}\text { Athayde } \\
\text { Ribeiro } \\
\text { Costa }\end{array}$ & $\begin{array}{l}\text { Ministéri } \\
\text { o } \\
\text { Público } \\
\text { Procurad } \\
\text { or da } \\
\text { Repúblic } \\
\text { a }\end{array}$ & $\begin{array}{llr}\text { Athayde } & \text { Ribeiro } & \text { Costa } \\
\text { (REDE } & \text { LFG - } & \text { Belo } \\
\text { Horizonte) } & \text { Milton Campos }\end{array}$ & & \\
\hline $\begin{array}{l}\text { Carlos } \\
\text { Fernando } \\
\text { dos Santos } \\
\text { Lima }\end{array}$ & $\begin{array}{l}\text { Ministéri } \\
\text { o } \\
\text { Público } \\
\text { Procurad } \\
\text { or da } \\
\text { Repúblic } \\
\text { a }\end{array}$ & $\begin{array}{l}\text { Cornell Law School. Master } \\
\text { of Laws (LL.M.), Crimes do } \\
\text { Colarinho Branco e e } \\
\text { Instituições } \\
\text { 2008-2009 }\end{array}$ & & $\begin{array}{l}\text { O pai Osvaldo e os irmãos } \\
\text { Luiz José e Paulo Ovídio } \\
\text { foram procuradores de } \\
\text { Justiça do MP-PR. } \\
\text { O pai Osvaldo dos Santos } \\
\text { Lima foi Deputado Estadual } \\
\text { pela ARENA. Presidente da } \\
\text { ALEP em 1973. }\end{array}$ \\
\hline $\begin{array}{l}\text { Diogo } \\
\text { Castor de } \\
\text { Mattos }\end{array}$ & $\begin{array}{l}\text { Ministéri } \\
\text { o } \\
\text { Público } \\
\text { Procurad } \\
\text { or da } \\
\text { Repúblic } \\
\text { a }\end{array}$ & $\begin{array}{l}\text { Estudou no Colégio Marista } \\
\text { Santa Maria, depois no } \\
\text { Colégio Dom Bosco em } \\
\text { Curitiba. Graduado em Direito } \\
\text { em } 2009 \text { pela PUCPR. Em } \\
2009 \text { foi estagiário do } \\
\text { procurador Deltan Dallagnol }\end{array}$ & $\begin{array}{l}\text { Procurador da } \quad \text { República } \\
\text { desde 2013. }\end{array}$ & $\begin{array}{l}\text { Filho do falecido procurador } \\
\text { de justiça Delivar Tadeu de } \\
\text { Mattos e de Maria Cristina } \\
\text { Jobim Castor de Mattos, irmã } \\
\text { do falecido Belmiro Jobim } \\
\text { Castor, ex-diretor do } \\
\text { Bamerindus, secretário de } \\
\text { Estado várias vezes no } \\
\text { Paraná nos anos 70-80 e do } \\
\text { Conselho Superior da } \\
\text { Associação Comercial do } \\
\text { Paraná. O escritório de } \\
\text { advocacia Delivar de Mattos } \\
\text { \& Castor é dos mais } \\
\text { conhecidos do Paraná, com } \\
\text { os irmãos Rodrigo Castor de } \\
\text { Mattos e Analice Castor de } \\
\text { Mattos. }\end{array}$ \\
\hline
\end{tabular}




\begin{tabular}{|c|c|c|c|c|c|}
\hline $\begin{array}{l}\text { Isabel } \\
\text { Cristina } \\
\text { Groba } \\
\text { Vieira }\end{array}$ & $\begin{array}{l}\text { Ministéri } \\
\text { o } \\
\text { Público. } \\
\text { Procurad } \\
\text { ora } \\
\text { Regional } \\
\text { da } \\
\text { Repúblic } \\
\text { a, lotada } \\
\text { na } \\
\text { Procurad } \\
\text { oria } \\
\text { Regional } \\
\text { da } \\
\text { Repúblic } \\
\text { a da } \\
\text { Terceira } \\
\text { Região, } \\
\text { em São } \\
\text { Paulo; }\end{array}$ & & $\begin{array}{l}\text { - em Direito, Universidade de } \\
\text { Brasília, em 1984; } \\
\text { - especialização em Direito na } \\
\text { UnB - curso de extensão } \\
\text { universitária; }\end{array}$ & $\begin{array}{l}\text { - entre 1987-1996 foi } \\
\text { analista de finanças e } \\
\text { controle externo do Tribunal } \\
\text { de Contas da União; } \\
\text { - atua no Ministério Público } \\
\text { Federal desde 1996; } \\
\text { - iniciou as atividades na } \\
\text { operação Lava-Jato em } \\
\text { 2016; }\end{array}$ & \\
\hline $\begin{array}{l}\text { Januário } \\
\text { Paludo }\end{array}$ & $\begin{array}{l}\text { Ministério } \\
\text { Público } \\
\text { Procurado } \\
\mathrm{r} \quad \text { da } \\
\text { República }\end{array}$ & & $\begin{array}{l}\text { Mestre em Direito pela USP; } \\
\text { Procurador Regional da } \\
\text { República }\end{array}$ & & \\
\hline $\begin{array}{l}\text { Jeruza } \\
\text { Burmann } \\
\text { Viecilli }\end{array}$ & $\begin{array}{l}\text { Ministéri } \\
\text { o } \\
\text { Público } \\
\text { Procurad } \\
\text { ora da } \\
\text { Repúblic } \\
\text { a }\end{array}$ & Ijuí/RS & $\begin{array}{l}\text { - em Direito, } \\
\text { Universidade Federal de Santa } \\
\text { Maria, formada em 2001; } \\
\text { - especializações na } \\
\text { Universidade da Amazônia } \\
\text { (2007) e na Pontifícia } \\
\text { Universidade Católica de São } \\
\text { Paulo (2010); }\end{array}$ & $\begin{array}{l}\text { - trabalhou no Ministério } \\
\text { Público Federal em Santa } \\
\text { Maria e em Porto Alegre; } \\
\text { - iniciou na Lava-Jato em } \\
\text { 2016; } \\
\text { - coordenadora estadual da } \\
\text { campanha } \\
\text { “10 Medidas contra a } \\
\text { Corrupção"; } \\
\text { - membro do Grupo de } \\
\text { Controle Externo da } \\
\text { Atividade Policial; } \\
\text { - coordenadora do Núcleo de } \\
\text { Tutela Coletiva; } \\
\text { - iniciou em } 2016 \text { as } \\
\text { atividades na Operação lava- } \\
\text { Jato; }\end{array}$ & \\
\hline $\begin{array}{l}\text { Julio Carlos } \\
\text { Motta } \\
\text { Noronha }\end{array}$ & $\begin{array}{l}\text { Ministéri } \\
\text { o } \\
\text { Público }\end{array}$ & & & $\begin{array}{l}\text { Empossado em } 2014 \text { como } \\
\text { procurador da república. } \\
\text { Assume os trabalhos na } \\
\text { Lava-Jato em julho de } 2015 \text {. }\end{array}$ & \\
\hline $\begin{array}{l}\text { Laura } \\
\text { Gonçalves } \\
\text { Tessler }\end{array}$ & $\begin{array}{l}\text { Procurad } \\
\text { ora do } \\
\text { Ministéri } \\
\text { o } \\
\text { Público } \\
\text { Federal }\end{array}$ & & $\begin{array}{l}\text { - Direito, pela Universidade } \\
\text { Federal do Paraná; }\end{array}$ & $\begin{array}{l}\text { - iniciou na Lava-Jato em } \\
\text { agosto de 2015; }\end{array}$ & \\
\hline
\end{tabular}




\begin{tabular}{|c|c|c|c|c|}
\hline $\begin{array}{l}\text { Orlando } \\
\text { Martello } \\
\text { Júnior }\end{array}$ & $\begin{array}{l}\text { Ministéri } \\
\text { o } \\
\text { Público } \\
\text { Procurad } \\
\text { or da } \\
\text { repúblic } \\
\text { a }\end{array}$ & Direito PUC-SP & $\begin{array}{l}\text { Em 2002, participou da } \\
\text { força-tarefa do Banestado. } \\
\text { 2010, assumiu o cargo de } \\
\text { procurador-chefe no Paraná }\end{array}$ & \\
\hline $\begin{array}{l}\text { Paulo } \\
\text { Roberto } \\
\text { Galvão de } \\
\text { Carvalho }\end{array}$ & $\begin{array}{l}\text { Ministéri } \\
\text { o } \\
\text { Público } \\
\text { Procurad } \\
\text { or da } \\
\text { Repúblic } \\
\text { a }\end{array}$ & $\begin{array}{l}\text { Direito pela Universidade } \\
\text { Federal da Bahia (UFBA) }\end{array}$ & $\begin{array}{l}\text { Em 2001 a } 2003 \text { foi } \\
\text { Defensor Público da União e } \\
\text { em 2003 a 2004 foi } \\
\text { Consultor Legislativo da } \\
\text { Câmara dos Deputados. Em } \\
\text { 2004 assumiu o cargo de } \\
\text { Procurador da República do } \\
\text { Ministério Público Federal. }\end{array}$ & \\
\hline $\begin{array}{l}\text { Roberson } \\
\text { Henrique } \\
\text { Pozzobon }\end{array}$ & $\begin{array}{l}\text { Ministéri } \\
\text { o } \\
\text { Público } \\
\text { Procurad } \\
\text { or da } \\
\text { Repúblic } \\
\text { a }\end{array}$ & $\begin{array}{l}\text { Graduado em } \begin{array}{l}\text { Direito pela } \\
\text { Pontifícia }\end{array} \\
\text { Universidade } \\
\text { Católica do Paraná em 2007, e } \\
\text { Mestre em Direito pela } \\
\text { PUCPR em 2010 }\end{array}$ & $\begin{array}{l}\text { Participa de eventos } \mathrm{e} \\
\text { palestras na igreja Batista. }\end{array}$ & \\
\hline
\end{tabular}

Elaboração dos autores 
PROSOPOGRAFIA DOS MEMBROS MINISTÉRIO TEMER (2016-2017)

\begin{tabular}{|c|c|c|c|c|c|}
\hline NOME & $\begin{array}{l}\text { MINISTE } \\
\text { RIO } \\
\text { Governo } \\
\text { Temer }\end{array}$ & $\begin{array}{l}\text { LOCAL/ } \\
\text { DATA } \\
\text { DE } \\
\text { NASCIM } \\
\text { ENTO }\end{array}$ & $\begin{array}{c}\text { FORMAÇ } \\
\tilde{\text { AOO }}\end{array}$ & CARGOS QUE ATUOU & REDE E ESTRUTURA FAMILIAR \\
\hline $\begin{array}{l}\text { Alexandre } \\
\text { de Moraes }\end{array}$ & JUSTIÇA & $\begin{array}{l}\text { São } \\
\text { Paulo, } \\
13 \text { de } \\
\text { dezembr } \\
\text { o de } \\
1968\end{array}$ & $\begin{array}{l}\text { Direito } \\
\text { USP. } \\
\text { Doutorado } \\
\text { e Professor }\end{array}$ & $\begin{array}{l}\text { Promotor de Justiça - MP-SP. CNJ. } \\
\text { Secretário de Justiça de SP. Secretário } \\
\text { de Segurança de SP. }\end{array}$ & \\
\hline $\begin{array}{l}\text { Osmar } \\
\text { Serraglio }\end{array}$ & JUSTIÇA & $\begin{array}{l}\text { Erechim, } \\
\text { RS } 1948\end{array}$ & $\begin{array}{l}\text { Faculdade } \\
\text { de Direito } \\
\text { Curitiba } \\
\text { Mestre em } \\
\text { Direito } \\
\text { PUC-SP }\end{array}$ & $\begin{array}{l}\text { Vice-prefeito de Umuarama } \\
\text { diretor da Faculdade de Direito da } \\
\text { Universidade Paranaense (UNIPAR) no } \\
\text { campus de Umuarama, } \\
\text { Deputado Federal pelo Paraná 1999- } \\
2017\end{array}$ & \\
\hline $\begin{array}{l}\text { Torquato } \\
\text { Jardim }\end{array}$ & JUSTIÇA & $\begin{array}{l}\text { Riode } \\
\text { Janeiro, } \\
12 \text { de } \\
\text { dezembr } \\
\text { o de } \\
1949 .\end{array}$ & $\begin{array}{l}\text { Faculdade } \\
\text { de Direito } \\
\text { de Brasília }\end{array}$ & $\begin{array}{l}\text { Assessor do Ministro Leitão de Abreu, } \\
\text { seu sogro na época. } \\
\text { Ministro do TSE }\end{array}$ & $\begin{array}{l}\text { Torquato Lorena Jardim, que é } \\
\text { membro da mais antiga família da } \\
\text { oligarquia da classe dominante } \\
\text { tradicional de Goiás. O Trisavô } \\
\text { Coronel José Rodrigues Jardim foi } \\
\text { Presidente da Província de Goiás no } \\
\text { Império, o mesmo que o bisavô } \\
\text { José Rodrigues Jardim Filho. O avô } \\
\text { Ten.Cel. Eugenio Rodrigues Jardim } \\
\text { também foi Presidente de Goiás e } \\
\text { Senador na República. O Pai } \\
\text { Coronel do Exército José Torquato } \\
\text { Caiado Jardim foi instrutor na } \\
\text { AMAN - Academia Militar das } \\
\text { Agulhas Negras (Resende - RJ). } \\
\text { Família de grandes latifundiários e } \\
\text { fazendeiros desde o tempo da } \\
\text { escravidão colonial no século } \\
\text { XVIII. Primo do Senador Ronaldo } \\
\text { Caiado, um dos chefes da bancada } \\
\text { ruralista de Goiás e de outra } \\
\text { importante oligarquia familiar da } \\
\text { região. }\end{array}$ \\
\hline $\begin{array}{l}\text { Aloysio } \\
\text { Nunes }\end{array}$ & $\begin{array}{l}\text { RELAÇÕ } \\
\text { ES } \\
\text { EXTERIO } \\
\text { RES }\end{array}$ & 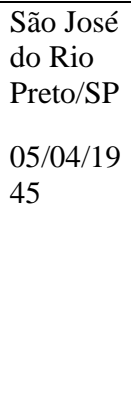 & $\begin{array}{l}\text { Direito } \\
\text { (USP) }\end{array}$ & $\begin{array}{l}\text { - advogado; } \\
\text { - durante os anos de } 1960 \text { esteve ligado } \\
\text { ao PCB (1963-1974); } \\
\text { - demais partidos políticos: MDB1974- } \\
\text { 1980, PMDB 1980-1997, PSDB 1997- } \\
\text { atual); } \\
\text { - deputado estadual 1983-1991, por SP; } \\
\text { - deputado federal 1995-2007, por SP; }\end{array}$ & $\begin{array}{l}\text { - casado com Gisele Sayeg Ferreira } \\
\text { Nunes, jornalista; } \\
\text { - filho do ex-deputado estadual } \\
\text { (1955-1958, 1959-1962) paulista } \\
\text { Aloysio Nunes Ferreira, advogado, } \\
\text { foi agricultor e pecuarista no } \\
\text { município de Jales, além de } \\
\text { vereador em São José do Rio Preto } \\
\text { (1951-1954); }\end{array}$ \\
\hline
\end{tabular}




\begin{tabular}{|c|c|c|c|c|c|}
\hline & & & & $\begin{array}{l}\text { - vice-governador de SP 1991-1995, ao } \\
\text { mesmo tempo também era secretário } \\
\text { estadual dos Negócios Metropolitanos; } \\
\text {-secretário da Casa civil de SP; } \\
\text { - Ministro da Justiça de 2001-2002; } \\
\text { - Senador licenciado 2011- atual. }\end{array}$ & \\
\hline $\begin{array}{l}\text { Blairo } \\
\text { Maggi }\end{array}$ & $\begin{array}{l}\text { AGRICU } \\
\text { LTURA }\end{array}$ & $\begin{array}{l}\text { Torres- } \\
\text { RS } \\
29 / 05 / 19 \\
56\end{array}$ & $\begin{array}{l}\text { Agronomi } \\
\text { a - UFPR }\end{array}$ & $\begin{array}{l}\text { Empresário, sojicultor } \\
\text { Senador } \\
\text { Governador de Mato Grosso }\end{array}$ & $\begin{array}{l}\text { Erai Maggi, primo. Conselho de } \\
\text { Desenvolvimento Econômico e } \\
\text { Social (CDES) }\end{array}$ \\
\hline $\begin{array}{l}\text { Bruno } \\
\text { Araújo }\end{array}$ & $\begin{array}{l}\text { CIDADE } \\
\mathrm{S}\end{array}$ & $\begin{array}{l}\text { Recife/P } \\
\text { E } \\
15 / 3 / 197 \\
2\end{array}$ & Direito. & $\begin{array}{l}\text { Oficial de Gabinete do Governador de } \\
\text { Pernambuco, Recife, PE, 1991; Chefe de } \\
\text { Gabinete de Deputado, ALEPE, Recife, } \\
\text { PE, 1992-1998; } \\
\text { Deputado Federal, 2007-2011, PE, } \\
\text { PSDB. Dt. Posse: 01/02/2007; Deputado } \\
\text { Federal, 2011-2015, PE, PSDB. Dt. } \\
\text { Posse: 01/02/2011; Deputado Federal, } \\
\text { 2015-2019, PE, PSDB. Dt. Posse: } \\
\text { 01/02/2015. }\end{array}$ & $\begin{array}{l}\text { Bruno Cavalcanti de Araújo. É filho } \\
\text { do ex-deputado estadual Eduardo } \\
\text { Gomes de Araújo, Maria de Nazaré } \\
\text { Leite Cavalcanti de Araújo. }\end{array}$ \\
\hline $\begin{array}{l}\text { Eliseu } \\
\text { Padilha }\end{array}$ & $\begin{array}{l}\text { CASA } \\
\text { CIVIL }\end{array}$ & $\begin{array}{l}\text { Canela, } \\
\text { RS, em } \\
1945 .\end{array}$ & $\begin{array}{l}\text { Formado } \\
\text { em direito } \\
\text { pela } \\
\text { Unisinos. }\end{array}$ & $\begin{array}{l}\text { Foi prefeito de Tramandaí, Deputado } \\
\text { Federal e Ministro dos Transportes no } \\
\text { governo de FHC. }\end{array}$ & \\
\hline $\begin{array}{l}\text { Fabiano } \\
\text { Augusto } \\
\text { Martins } \\
\text { Silveira }\end{array}$ & $\begin{array}{l}\text { FISCALI } \\
\text { ZAÇÃO, } \\
\text { TRANSP } \\
\text { ARÊNCI } \\
\text { A E E } \\
\text { CONTRO } \\
\text { LE }\end{array}$ & $\begin{array}{l}\begin{array}{l}\text { Belo } \\
\text { Horizont } \\
\text { e/MG }\end{array} \\
\text { 19/12/19 } \\
74\end{array}$ & $\begin{array}{l}\text { - Bacharel, } \\
\text { Mestre e } \\
\text { Doutor em } \\
\text { Direito, } \\
\text { pela } \\
\text { Universida } \\
\text { de Federal } \\
\text { de Minas } \\
\text { Gerais; }\end{array}$ & $\begin{array}{l}\text { - advogado; } \\
\text { - professor Universitário; } \\
\text { - consultor Legislativo do senado } \\
\text { Federal, aprovado em concurso público } \\
\text { em 2002; } \\
\text {-conselheiro do Conselho Nacional do } \\
\text { Ministério Público, 2011-2013; } \\
\text { - conselheiro do Conselho Nacional de } \\
\text { Justiça, 2013-2015 - cargo obtido por } \\
\text { indicação de Renan Calheiros; }\end{array}$ & $\begin{array}{l}\text { * foi o segundo Ministro de Temer } \\
\text { a cair por aparecer em gravações } \\
\text { indicando o uso da máquina pública } \\
\text { para favorecimento de aliados } \\
\text { ligados à corrupção; - é casado com } \\
\text { Gylwania Peres Machado, neta de } \\
\text { Erotides Costa Machado, militar, } \\
\text { comerciante e barqueiro tradicional } \\
\text { de Pedro Afonso (TO) - filiado ao } \\
\text { PP (Partido Progressista) desde } \\
\text { 1992; - filho de Sebastiana, que } \\
\text { pertence à família tradicional de } \\
\text { Pedro Afonso (TO);- filho de } \\
\text { Afonso Celso Silveira, uberabense, } \\
\text { exerce advocacia em belo } \\
\text { Horizonte; } \\
\text {-sobrinho de Paulo Fernando } \\
\text { Silveira, juiz federal em Uberaba, } \\
\text { MG;-sobrinho de José Orlando } \\
\text { Silveira, coronel; }\end{array}$ \\
\hline $\begin{array}{l}\text { Fábio } \\
\text { Medina } \\
\text { Osório }\end{array}$ & $\begin{array}{l}\text { ADVOCA } \\
\text { CIA } \\
\text { GERAL } \\
\text { DA } \\
\text { UNIÃO }\end{array}$ & $\begin{array}{l}\text { Porto } \\
\text { Alegre/R } \\
\text { S } \\
31 / 07 / 19 \\
67\end{array}$ & Direito & $\begin{array}{l}\text { 1991-2006: Promotor de justiça no } \\
\text { Ministério Público/RS } \\
\text { 2007: pede exoneração e abre escritório } \\
\text { Medina Osório Advogados } \\
\text { 2003-2005: Secretaria adjunto da justiça } \\
\text { e segurança do RS (governo Germano }\end{array}$ & $\begin{array}{l}\text { Especializado em leis } \text { sobre } \\
\text { combate à corrupção. }\end{array}$ \\
\hline
\end{tabular}




\begin{tabular}{|c|c|c|c|c|c|}
\hline & & & & $\begin{array}{l}\text { Rigotto) } \\
\text { 12/05 a 09/09/2016: Advogado geral da } \\
\text { União do governo Temer }\end{array}$ & \\
\hline $\begin{array}{l}\text { Fernando } \\
\text { Coelho } \\
\text { Filho }\end{array}$ & $\begin{array}{l}\text { MINAS E } \\
\text { ENERGI } \\
\text { A }\end{array}$ & $\begin{array}{l}\text { Recife/P } \\
\text { E } \\
28 / 2 / 198 \\
4\end{array}$ & $\begin{array}{l}\text { Administra } \\
\text { dor de } \\
\text { Empresas }\end{array}$ & $\begin{array}{l}\text { Deputado Federal, 2007-2011, PE, PSB. } \\
\text { Dt. Posse: 01/02/2007; Deputado } \\
\text { Federal, 2011-2015, PE, PSB. Dt. Posse: } \\
\text { 01/02/2011; Deputado Federal, 2015- } \\
\text { 2019, PE, PSB. Dt. Posse: 01/02/2015 }\end{array}$ & $\begin{array}{l}\text { Fernando Coelho Filho (PSB) é } \\
\text { filho do ex-deputado, ex-prefeito de } \\
\text { Petrolina (PE) e ex-ministro da } \\
\text { Integração Nacional, e atual } \\
\text { Senador Fernando Bezerra Coelho } \\
\text { (PSB) e é sobrinho-neto do } \\
\text { ex-deputado estadual } \\
\text { ex-governador de Pernambuco e } \\
\text { ex-senador Nilo Coelho e do o } \\
\text { ex-deputado federal Osvaldo } \\
\text { Coelho. Também é sobrinho do } \\
\text { ex-deputado Clementino Coelho. }\end{array}$ \\
\hline $\begin{array}{l}\text { Geddel } \\
\text { Vieira } \\
\text { Lima }\end{array}$ & $\begin{array}{l}\text { SECRET } \\
\text { ARIA DE } \\
\text { GOVERN } \\
\text { O }\end{array}$ & $\begin{array}{l}\text { Salvador } \\
\text { /BA } \\
18 / 03 / 19 \\
59\end{array}$ & $\begin{array}{l}\text { Administr } \\
\text { ador de } \\
\text { empresas }\end{array}$ & $\begin{array}{l}\text { Deputado Federal (Congresso Revisor), } \\
\text { 1991-1995, BA, PMDB. Dt. Posse: } \\
\text { 01/02/1991; Deputado Federal, 1995- } \\
\text { 1999, BA, PMDB. Dt. Posse: } \\
\text { 01/02/1995; Deputado Federal, 1999- } \\
\text { 2003, BA, PMDB. Dt. Posse: } \\
\text { 01/02/1999; Deputado Federal, 2003- } \\
\text { 2007, BA, PMDB. Dt. Posse: } \\
\text { 01/02/2003; Deputado Federal, 2007- } \\
\text { 2011, BA, PMDB. Dt. Posse: } \\
\text { 01/02/2007. Ministro da Integração } \\
\text { Nacional. }\end{array}$ & $\begin{array}{l}\text { Geddel Quadros Vieira Lima } \\
\text { (PMDB) é casado com Alessandra } \\
\text { Vieira Lima. Filho do ex-deputado } \\
\text { estadual e ex-deputado federal } \\
\text { Aprísio Vieira Lima e de Marluce } \\
\text { Quadros Vieira Lima. Irmão de } \\
\text { Lúcio Vieira Lima (PMDB), } \\
\text { ex-vereador, ex-deputado estadual e } \\
\text { deputado federal. É irmão de } \\
\text { Afrísio Vieira Lima Filho. }\end{array}$ \\
\hline $\begin{array}{l}\text { Gilberto } \\
\text { Kassab }\end{array}$ & $\begin{array}{l}\text { CIÊNCIA, } \\
\text { TENOLO } \\
\text { GIA, } \\
\text { INOVAÇ } \\
\tilde{A O} \quad \text { E } \\
\text { COMUNI } \\
\text { CAÇÕES }\end{array}$ & $\begin{array}{l}\text { São } \\
\text { Paulo/SP } \\
12 / 08 / 19 \\
60\end{array}$ & $\begin{array}{l}\text { Economia } \\
\text { e } \\
\text { engenheiro } \\
\text { civil }\end{array}$ & $\begin{array}{l}\text { 1992-1995: vereador de São Paulo pelo } \\
\text { PL (hoje PR). 1995: deputado } \\
\text { estadual/SP. 1997-1998: Secretário } \\
\text { Municipal de Planejamento (Celso } \\
\text { Pitta). 1999-2005: deputado federal/SP. } \\
\text { 2004-2007: eleito vice-prefeito de SP } \\
\text { (chapa José Serra). 2006: assume como } \\
\text { prefeito de SP. 2008-2011: prefeito de } \\
\text { SP. 2015-2016: Ministro das Cidades } \\
\text { (governo Dilma). 2016: Ministro } \\
\text { Ciência, Tecnologia, Inovação e } \\
\text { Comunicações (governo Temer) }\end{array}$ & $\begin{array}{l}\text { Filho do médico Pedro Salomão } \\
\text { José Kassab e da professora Yacy } \\
\text { Palermo Kassab. Origem libanesa. } \\
\text { O pai Pedro Kassab foi secretário- } \\
\text { geral (1963-1969) e presidente } \\
\text { (1969-1981) da Associação Médica } \\
\text { Brasileira (AMB) por seis mandatos } \\
\text { consecutivos. Em } 1976 \text { foi eleito } \\
\text { presidente da Associação Médica } \\
\text { Mundial. Foi membro das seguintes } \\
\text { entidades: Conselho Deliberativo da } \\
\text { Casa da Cultura Francesa - Aliança } \\
\text { Francesa de São Paulo, chegando a } \\
\text { vice-presidente; Ordem dos Velhos } \\
\text { Jornalistas de São Paulo; Academia } \\
\text { de Medicina de São Paulo } \\
\text { (honorário); Associação Paulista de } \\
\text { Fundações; Conselho Estadual de } \\
\text { Educação (desde 2003, sendo eleito } \\
\text { presidente para o biênio 2006- } \\
\text { 2007); Fundação Educacional } \\
\text { Inaciana Padre Sabóia de Medeiros, } \\
\text { mantenedora do Centro } \\
\text { Universitário da FEI - Faculdade de } \\
\text { Engenharia Industrial (diretor e } \\
\text { vice-presidente); Conselho Federal } \\
\text { de Medicina (1969- 1974); } \\
\text { Conselho Nacional de Saúde (1974- } \\
\text { 1978); Conselho dos Curadores da } \\
\text { Fundação Antônio Prudente (desde } \\
\text { 1974); Conselho de Economia, }\end{array}$ \\
\hline
\end{tabular}




\begin{tabular}{|c|c|c|c|c|c|}
\hline & & & & & $\begin{array}{l}\text { Sociologia e Política da Federação } \\
\text { do Comércio do Estado de São } \\
\text { Paulo (1978); Conselho de Ética de } \\
\text { Autorregulamentação Publicitária - } \\
\text { Conar, desde seu início em } 1980 \text { e, } \\
\text { recebendo no } 25 \text { aniversário dessa } \\
\text { instituição, o título de sócio } \\
\text { honorário; Conselho Curador da } \\
\text { Fundação Antônio Prudente, } \\
\text { mantenedora do Hospital do Câncer } \\
\text { A. C. Camargo; Conselho } \\
\text { Consultivo do CIEE - Centro de } \\
\text { Integração Empresa-Escola } \\
\text { (honorário); e Academia Paulista de } \\
\text { Educação, ingressando em } \\
\text { 20/4/2004, na cadeira no } 35 \text { sob o } \\
\text { patrono de Newton de Almeida } \\
\text { Mello. Em 2009 foi eleito membro } \\
\text { da cadeira no 25 da Academia } \\
\text { Paulista de Letras, na vaga deixada } \\
\text { pelo geneticista Crodowaldo Pavan, } \\
\text { falecendo, contudo, pouco antes de } \\
\text { sua posse solene. Gilberto Kassab } \\
\text { não tem esposa e nem filhos. }\end{array}$ \\
\hline $\begin{array}{l}\text { Helder } \\
\text { Barbalho }\end{array}$ & $\begin{array}{l}\text { INTEGR } \\
\text { AÇÃO } \\
\text { NACION } \\
\text { AL }\end{array}$ & $\begin{array}{l}\text { Belém } \\
\text { do Pará, } \\
\text { no dia } 18 \\
\text { de maio } \\
\text { de } 1979 .\end{array}$ & $\begin{array}{l}\text { Pós- } \\
\text { graduado } \\
\text { em Gestão } \\
\text { Pública } \\
\text { pela FGV- } \\
\text { SP, com o } \\
\text { título de } \\
\text { MBA } \\
\text { Executivo } \\
\text { em Gestão } \\
\text { Pública. } \\
\text { Graduado } \\
\text { em } \\
\text { Administra } \\
\text { ção 2002, } \\
\text { pela } \\
\text { Universida } \\
\text { de da } \\
\text { Amazônia } \\
\text { (Unama). }\end{array}$ & $\begin{array}{l}\text { Foi vereador e prefeito em Ananindeua, } \\
\text { deputado estadual, Ministro da Pesca. }\end{array}$ & $\begin{array}{l}\text { Helder Zahluth Barbalho }{ }^{18} \text { é filho } \\
\text { do ex-governador do Pará, Jader } \\
\text { Barbalho, e da deputada federal } \\
\text { Elcione Barbalho. }\end{array}$ \\
\hline $\begin{array}{l}\text { Henrique } \\
\text { Alves }\end{array}$ & $\begin{array}{l}\text { TURISM } \\
\mathrm{O}\end{array}$ & $\begin{array}{l}\text { Rio de } \\
\text { Janeiro/ } \\
\text { RJ } \\
\text { 09/12/19 } \\
48\end{array}$ & $\begin{array}{l}\text { Direito } \\
\text { (UFRJ) } \\
\text { Empresári } \\
\text { o. }\end{array}$ & $\begin{array}{l}\text { Deputado Federal, 1971-1975-1979, RN, } \\
\text { MDB. Dt. Posse: 01/02/1975; Deputado } \\
\text { Federal, 1979-1983, RN, MDB. Dt. } \\
\text { Posse: 01/02/1979; Deputado Federal, } \\
\text { 1983-1987, RN, PMDB. Dt. Posse: } \\
\text { 01/02/1983; Deputado } \\
\text { (Constituinte), } 1987-1991, \text { FN, PMDB. } \\
\text { Dt. Posse: 01/02/1987; Deputado } \\
\text { Federal (Congresso Revisor), 1991- } \\
\text { 1995, RN, PMDB. Dt. Posse: } \\
\text { 01/02/1991; Deputado Federal, 1995- } \\
\text { 1999, RN, PMDB. Dt. Posse: } \\
\text { 01/02/1995; Deputado Federal, 1999- } \\
\text { 2003, RN, PMDB. Dt. Posse: } \\
\text { 01/02/1999; Deputado Federal, 2003- }\end{array}$ & 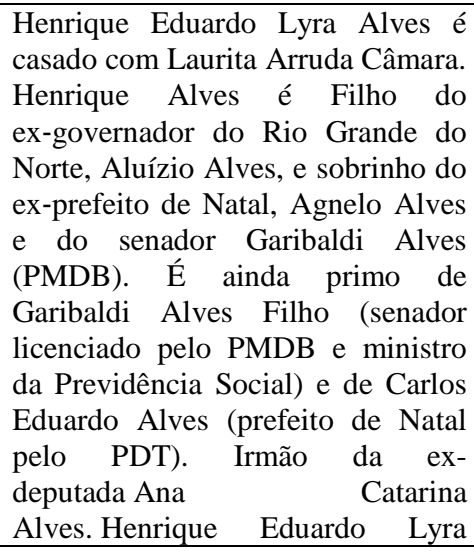 \\
\hline
\end{tabular}

\footnotetext{
${ }^{18}$ Disponível em http://www.mi.gov.br/perfil. Acesso 18.junho.2017.
} 


\begin{tabular}{|c|c|c|c|c|c|}
\hline & & & & 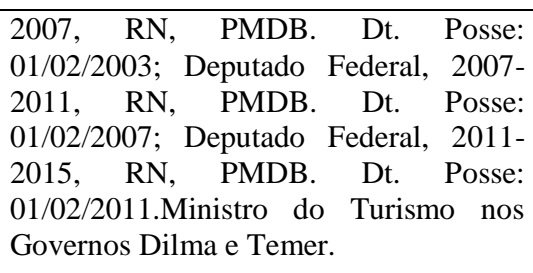 & $\begin{array}{l}\text { Alves é um dos proprietários da TV } \\
\text { Cabugi, afiliada da Globo no Rio } \\
\text { Grande do Norte, da Rádio Cabugi } \\
\text { e do jornal Tribuna do Norte. É o } \\
\text { decano da Câmara dos Deputados, } \\
\text { com } 11 \text { mandatos seguidos pelo Rio } \\
\text { Grande do Norte. }\end{array}$ \\
\hline $\begin{array}{l}\text { Henrique } \\
\text { Meirelles }\end{array}$ & $\begin{array}{l}\text { FAZEND } \\
\text { A/ } \\
\text { PREVIDÊ } \\
\text { NCIA }\end{array}$ & $\begin{array}{l}31 / 08 / 19 \\
45\end{array}$ & $\begin{array}{l}- \\
\text { Engenheir } \\
\text { o, pela } \\
\text { Escola } \\
\text { Politécnica } \\
\text { da } \\
\text { Universida } \\
\text { de de São } \\
\text { Paulo; } \\
\text {-faz parte } \\
\text { do } \\
\text { Conselho } \\
\text { de várias } \\
\text { instituiçõe } \\
\text { s de ensino } \\
\text { nacionais e } \\
\text { internacion } \\
\text { ais } \\
\text { agraciado } \\
\text { com o } \\
\text { título } \\
\text { doutor } \\
\text { honoris } \\
\text { causa, } \\
\text { pelo } \\
\text { Bryant } \\
\text { College; }\end{array}$ & $\begin{array}{l}\text {-ex-presidente internacional do } \\
\text { BankBoston- nacional e internacional - } \\
\text { (1974-2002); } \\
\text { - ex-presidente do Banco Central do } \\
\text { Brasil (2003-2011); } \\
\text { - deputado federal por Goiás (2002- } \\
\text { 2003, quando renunciou para assumir o } \\
\text { Banco Central); }\end{array}$ & $\begin{array}{l}\text { - filho de Hegesipo de Campos } \\
\text { Meirelles, que foi interventor } \\
\text { federal em Goiás (1946-1947), e } \\
\text { advogado do Banco do Estado de } \\
\text { Goiás; } \\
\text { - filho de Diva Silva de Campos, } \\
\text { estilista; } \\
\text { - seu tio, Jonas Ferreira Alves } \\
\text { Duarte, foi vice-governador em } \\
\text { 1951-1954, prefeito de Anápolis } \\
\text { (1962-1966, secretário municipal de } \\
\text { educação em Anápolis (1975- } \\
\text { 1978); } \\
\text { - seu primo, Aldo Arantes, foi } \\
\text { presidente da UNE (1961-1962) e } \\
\text { deputado federal (1982-1986 como } \\
\text { suplente, 1987-1990, 1995-1999, } \\
\text { 2001-2003), além de vereador } \\
\text { (1992-1995); } \\
\text {-seu primo, Haroldo Duarte, foi } \\
\text { deputado federal (1963-1967); }\end{array}$ \\
\hline $\begin{array}{l}\text { Ilan } \\
\text { Goldfajn }\end{array}$ & $\begin{array}{l}\text { BANCO } \\
\text { CENTRA } \\
\text { L }\end{array}$ & 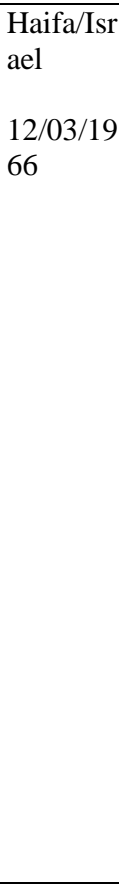 & Economia & $\begin{array}{l}\text { Economista Chefe e Sócio, Itaú- } \\
\text { Unibanco (abr/2009 - mai/2016) } \\
\text { Diretor Centro Debate Políticas Públicas } \\
\text { (jul/2013 - mai/2016); } \\
\text { Economista, Ciano Assessoria } \\
\text { Econômica (set/2008 - abr/2009); } \\
\text { Sócio, Ciano Investimentos (jan/2007 - } \\
\text { ago/2008); } \\
\text { Diretor do Instituto de Estudos de } \\
\text { Política Econômica da Casa das Garças - } \\
\text { IEPE-CdG (jan/2006 - abril/2009). } \\
\text { Sócio e Economista, Gávea } \\
\text { Investimentos (nov/2003 - jun/2006); } \\
\text { Diretor de Política Econômica, Banco } \\
\text { Central do Brasil (set/2000 - jul/2003); } \\
\text { Consultor de organizações } \\
\text { internacionais (Banco Mundial, Fundo } \\
\text { Monetário Internacional e Nações } \\
\text { Unidas), bancos internacionais, governo }\end{array}$ & $\begin{array}{l}\text { Casado com Denise Goldfajn. Tem } \\
3 \text { filhos. }\end{array}$ \\
\hline
\end{tabular}




\begin{tabular}{|c|c|c|c|c|c|}
\hline & & & & $\begin{array}{l}\text { Brasileiro e bancos (fev/99 - set/2000); } \\
\text { Professor Assistente, Departamento de } \\
\text { Economia, PUC-RJ (fev/1999 - } \\
\text { abr/2009). } \\
\text { Economista, FMI (out/1996 - jan/1999); } \\
\text { Professor Assistente, Brandeis } \\
\text { University (set/1995 - ago/1996); }\end{array}$ & \\
\hline $\begin{array}{l}\text { José } \\
\text { Mendonça } \\
\text { Bezerra } \\
\text { Filho }\end{array}$ & $\begin{array}{l}\text { EDUCAÇ } \\
\tilde{A} O\end{array}$ & $\begin{array}{l}\text { Recife/P } \\
\text { E } \\
12 / 07 / 19 \\
66\end{array}$ & $\begin{array}{l}\text { Administra } \\
\text { ção de } \\
\text { Empresas } \\
\text { (UFPE). } \\
\text { Especializ } \\
\text { ação na } \\
\text { área de } \\
\text { gestão } \\
\text { pública } \\
\text { pela } \\
\text { Kennedy } \\
\text { School. }\end{array}$ & $\begin{array}{l}\text { Deputado Estadual. } \\
\text { Secretaria de Agricultura } \\
\text { Deputado Federal } \\
\text { Vice-governador de Pernambuco, por } \\
\text { dois mandatos. }\end{array}$ & $\begin{array}{l}\text { Mendonça Filho é casado com } \\
\text { Tatiana Vilaça Mendonça. Esta que } \\
\text { é filha do ex-ministro do TCU } \\
\text { Marcos Vinicius Vilaça. Este que } \\
\text { foi casado com a bisneta de } \\
\text { Otaviano Heráclio do Rêgo, Tio- } \\
\text { bisavó do atual Ministro Vital do } \\
\text { Rêgo Filho. Mendonça Filho } \\
\text { (DEM). Filho do ex-deputado } \\
\text { estadual e federal (Sete vezes) } \\
\text { latifundiário José Mendonça } \\
\text { Bezerra (DEM-PE), irmão da } \\
\text { ex-secretária de Turismo, Cultura e } \\
\text { Paisagismo de Belo Jardim (PE) } \\
\text { Andrea Mendonça (DEM-PE), } \\
\text { cunhado do deputado federal } \\
\text { Augusto Coutinho (DEM-PE). } \\
\text { Augusto Coutinho é empresário } \\
\text { ligado à construção civil. Fundou o } \\
\text { Belo Jardim Futebol Clube e } \\
\text { ocupou postos de comando no } \\
\text { Santa Cruz Futebol Clube. Foi } \\
\text { diretor do Sindicato da Construção } \\
\text { Civil de Recife (1988-1990). Foi } \\
\text { vereador de Recife pelo PFL (1993- } \\
\text { 1997/ 1997-2001) e deputado } \\
\text { estadual pelo mesmo partido (1999- } \\
\text { 2003/ 2003-2007) e pelo DEM } \\
\text { (2007-2011). Foi secretário } \\
\text { municipal de Governo (1993-1995/ } \\
\text { 1996-1998) e de Habitação (2001- } \\
\text { 2002). Mendonça Filho é primo do } \\
\text { ex-prefeito de Belo Jardim, João } \\
\text { Mendonça (PSD). Este que foi } \\
\text { cassado pelo TSE em 11/05/2017, } \\
\text { acusado de improbidade } \\
\text { administrativa e enriquecimento } \\
\text { ilícito. }\end{array}$ \\
\hline $\begin{array}{l}\text { José } \\
\text { Sarney } \\
\text { Filho }\end{array}$ & $\begin{array}{l}\text { MEIO } \\
\text { AMBIEN } \\
\text { TE }\end{array}$ & $\begin{array}{l}\text { São } \\
\text { Luis/MA } \\
14 / 6 / 195 \\
7\end{array}$ & $\begin{array}{l}\text { Direito, } \\
\text { Universida } \\
\text { de Federal } \\
\text { do } \\
\text { Maranhão, } \\
\text { São Luís, } \\
\text { 1981; } \\
\text { Economia, } \\
\text { Pontifícia }\end{array}$ & $\begin{array}{l}\text { Secretário para Assuntos Políticos, } \\
\text { Estado do Maranhão, 1988, 1989-1990; } \\
\text { Ministro de Estado do Meio Ambiente, } \\
\text { 1999-2002. } \\
\text { Deputado Estadual (1979 a 1983) }\end{array}$ & $\begin{array}{l}\text { Sarney Filho (PV) é de família de } \\
\text { políticos, entre eles, o pai José } \\
\text { Sarney (ex-presidente da República } \\
\text { e ex-senador pelo (PMDB-MA) e a } \\
\text { irmã Roseana Sarney } \\
\text { governadora do Maranhão pelo } \\
\text { PMDB-MA). }\end{array}$ \\
\hline
\end{tabular}




\begin{tabular}{|c|c|c|c|c|c|}
\hline & & & $\begin{array}{l}\text { Universida } \\
\text { de } \\
\text { Católica, } \\
\text { São Paulo, } \\
\text { SP. }\end{array}$ & & \\
\hline José Serra & $\begin{array}{l}\text { RELAÇÕ } \\
\text { ES } \\
\text { EXTERIO } \\
\text { RES }\end{array}$ & $\begin{array}{l}\text { São } \\
\text { Paulo/SP } \\
\\
19 / 03 / 19 \\
42\end{array}$ & $\begin{array}{l}\text { - } \\
\text { Engenhari } \\
\text { a (não } \\
\text { concluído), } \\
\text { pela } \\
\text { Universida } \\
\text { de de São } \\
\text { Paulo; } \\
\text { - } \\
\text { Economia, } \\
\text { pela } \\
\text { Faculdade } \\
\text { de } \\
\text { Economia } \\
\text { da } \\
\text { Universida } \\
\text { de do } \\
\text { Chile; } \\
\text {-Mestrado } \\
\text { e } \\
\text { Doutorado } \\
\text { Universida } \\
\text { de de } \\
\text { Cornell, } \\
\text { Ithaca. }\end{array}$ & $\begin{array}{l}\text { - professor em várias universidades } \\
\text { nacionais e internacionais; } \\
\text { - deputado federal por SP (1987-1991, } \\
\text { 1991-1995); } \\
\text { - senador (1995-2003); } \\
\text { - ocupou o Ministério do Planejamento e } \\
\text { Orçamento (1995-1996) e o Ministério } \\
\text { da Saúde (1998-2002); } \\
\text {-prefeito de São Paulo (2005-2006); } \\
\text {-governador de São Paulo (2007-2010); } \\
\text { - senador (2015-2023); }\end{array}$ & $\begin{array}{l}\text { - casado com Mônica Allende } \\
\text { Serra, psicoterapeuta chilena; } \\
\text { - pai de Verônica Serra e de } \\
\text { Luciano Serra; }\end{array}$ \\
\hline $\begin{array}{l}\text { Leonardo } \\
\text { Picciani }\end{array}$ & $\begin{array}{l}\text { ESPORT } \\
\text { E }\end{array}$ & $\begin{array}{l}\text { nascido } \\
\text { em } \\
06.11 .19 \\
79, \\
\text { Nilópolis } \\
\text {, Rio de } \\
\text { Janeiro }\end{array}$ & $\begin{array}{l}\text { Direito - } \\
\text { Universida } \\
\text { de } \\
\text { Candido } \\
\text { Mendes } \\
\text { UCAM } \\
\text { Agropecua } \\
\text { rista }\end{array}$ & $\begin{array}{l}\text { exerce o quarto mandato consecutivo de } \\
\text { deputado federal pelo PMDB do Rio de } \\
\text { Janeiro. Foi secretário de Estado de } \\
\text { Habitação do Rio de Janeiro, entre } 2009 \\
\text { e } 2011 \text {, e assessor da Presidência do } \\
\text { Tribunal de Contas do Rio de Janeiro, } \\
\text { entre } 1998 \text { e } 2002 \text {. }\end{array}$ & $\begin{array}{l}\text { Leonardo Carneiro Monteiro } \\
\text { Picciani }{ }^{19} \text { é casado e pai de três } \\
\text { filhos. Leonardo Picciani é filho de } \\
\text { Jorge Picciani, Deputado Estadual, } \\
\text { Presidente da Assembleia } \\
\text { Legislativa do Rio de Janeiro }{ }^{20} \text {. O } \\
\text { irmão de Leonardo Picciani é } \\
\text { Rafael Picciani, Deputado Estadual } \\
\text { e Secretário de Estado. Outro irmão } \\
\text { de Leonardo Picciani é Felipe } \\
\text { Picciani, executivo no Grupo Monte } \\
\text { Verde ligado à família. }\end{array}$ \\
\hline $\begin{array}{l}\text { Marcelo } \\
\text { Calero }\end{array}$ & $\begin{array}{l}\text { CULTUR } \\
\text { A }\end{array}$ & $\begin{array}{ll}7 & \text { de } \\
\text { julho de } \\
\text { Rio de } \\
\text { Janeiro }\end{array}$ & $\begin{array}{l}\text { Direito } \\
\text { (UERJ) e } \\
\text { diplomata }\end{array}$ & $\begin{array}{l}\text { Secretário de cultura da Prefeitura do } \\
\text { Rio de Janeiro em } 2015 \text {, }\end{array}$ & \\
\hline $\begin{array}{l}\text { Marcos } \\
\text { Antônio } \\
\text { Pereira }\end{array}$ & $\begin{array}{l}\text { DESENV } \\
\text { OLVIME } \\
\text { NTO, } \\
\text { INDÚST } \\
\text { RIA E E } \\
\text { COMÉRC }\end{array}$ & $\begin{array}{l}\text { Linhares } \\
\text { /ES } \\
04 / 04 / 19 \\
72\end{array}$ & Direito & $\begin{array}{l}\text { Diretor administrativo e financeiro da } \\
\text { TV Record/RJ (1995-1999). Diretor } \\
\text { Rede Mulher de Televisão (1999-2003). } \\
\text { Vice-presidente da Rede Record de } \\
\text { Televisão (à partir 2003). Sócio na LM } \\
\text { Consultoria Contábil (2003-2013). } \\
\text { Fundador Pereira, Moraes e Oliveira }\end{array}$ & $\begin{array}{l}\text { Bispo licenciado da Igreja } \\
\text { Universal do Reino de Deus. Faz } \\
\text { parte da bancada evangélica da } \\
\text { Câmara dos Deputados. Casado } \\
\text { com Margareth Pereira.Vem da área } \\
\text { privada. É o presidente nacional do }\end{array}$ \\
\hline
\end{tabular}

${ }^{19}$ Disponível em http://www.esporte.gov.br/index.php/institucional/o-ministerio/ministro. Acesso 18.junho.2017.

20 Disponível em https://oglobo.globo.com/brasil/familia-picciani-ganha-projecao-nacional-com-politica-brasileira21128582. Acesso 18.junho.2017. 


\begin{tabular}{|c|c|c|c|c|c|}
\hline & IO & & & $\begin{array}{l}\text { Sociedade de Advogados (2013). } \\
\text { Professor do Instituto Brasiliense de } \\
\text { Direito Público }\end{array}$ & PRB. \\
\hline $\begin{array}{l}\text { Maurício } \\
\text { Quintella } \\
\text { Lessa }\end{array}$ & $\begin{array}{l}\text { TRANSP } \\
\text { ORTE/PO } \\
\text { RTO/AVI } \\
\text { AÇÃO } \\
\text { CIVIL }\end{array}$ & $\begin{array}{l}\text { Maceió/ } \\
\text { AL } \\
28 / 03 / 19 \\
71\end{array}$ & $\begin{array}{l}\text { Engenhari } \\
\text { a Civil, } \\
\text { UFAL, } \\
\text { Maceió, } \\
\text { AL, 1989- } \\
\text { 1990; } \\
\text { Direito, } \\
\text { Centro de } \\
\text { Ensino } \\
\text { Superior } \\
\text { de Maceió, } \\
\text { AL, 1992- } \\
\text { 1995. }\end{array}$ & $\begin{array}{l}\text { Deputado Federal (Três mandados). } \\
\text { Vereador, Maceió/AL, Partido: PSB, } \\
\text { Período: 1997 a 2000 Vereador, } \\
\text { Maceió/AL, Partido: PSB, Período: 2001 } \\
\text { a 2003. Técnico Judiciário, TRT, } \\
\text { Maceió, AL, 1992-; Secretário } \\
\text { Municipal da Educação, Prefeitura de } \\
\text { Maceió, AL, 1997-1999; Secretário } \\
\text { Extraordinário Regional Metropolitano, } \\
\text { AL, 2003-2004; Secretário de Educação, } \\
\text { AL, 2004-2005. }\end{array}$ & $\begin{array}{l}\text { Maurício Quintela Malta } \\
\text { Lessa nasceu em Maceió no dia } 28 \\
\text { de março de 1971, filho de José } \\
\text { Márcio Malta Lessa e de Laura } \\
\text { Quintela Malta Lessa. Seu pai foi } \\
\text { superintendente de energia e } \\
\text { iluminação pública de Maceió na } \\
\text { gestão de Cícero Almeida, iniciada } \\
\text { em 2005, e seu tio, Ronaldo } \\
\text { Lessa, foi governador de Alagoas } \\
\text { de 1999 a 2006.Maurício Quintella } \\
\text { Malta Lessa. É primo de Ronaldo } \\
\text { Lessa (PDT-AL), ex-governador de } \\
\text { Alagoas e deputado federal eleito } \\
\text { em 2014 e filho de José Márcio } \\
\text { Malta Lessa, ex-secretário de } \\
\text { Educação. }\end{array}$ \\
\hline $\begin{array}{l}\text { Osmar } \\
\text { Terra }\end{array}$ & $\begin{array}{l}\text { DESENV } \\
\text { OLVIME } \\
\text { NTO } \\
\text { SOCIAL } \\
\text { E } \\
\text { AGRÁRI } \\
\text { O }\end{array}$ & $\begin{array}{l}\text { Porto } \\
\text { Alegre } \\
18 / 02 / 19 \\
50\end{array}$ & Medicina & $\begin{array}{l}\text { 1986-1988: } \\
\text { INAMPS/POA. 1989-1990: diretor } \\
\text { Secretaria de Saúde/RS.1993-1996: } \\
\text { prefeito de Santa Rosa/RS. 1997-1998: } \\
\text { chefe de gabinete do governo do RS } \\
\text { 1999-2001: Secretário exec. Programa } \\
\text { Comunidade Solidária/CTBA. 2001- } \\
\text { 2003: assumiu como suplente dep. } \\
\text { fed.1/RS. 2003-2005: Secretário de } \\
\text { Saúde do RS. 2005-2007: suplente dep. } \\
\text { fed.1/RS. 2007-19 dep. federal/RS }\end{array}$ & $\begin{array}{l}\text { Filho de Walter Paim Terra e Nelly } \\
\text { Lúcia Gasparini Terra }\end{array}$ \\
\hline $\begin{array}{l}\text { Raul } \\
\text { Julgmann }\end{array}$ & DEFESA & $\begin{array}{l}\text { Recife/P } \\
\text { E } \\
03 / 04 / 19 \\
52\end{array}$ & & 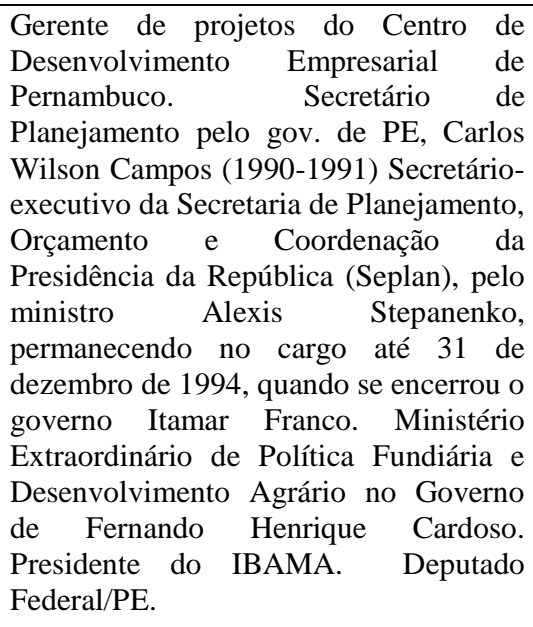 & $\begin{array}{l}\text { Raul Belens Jungmann Pinto. Filho } \\
\text { de Sílvio Jungmann da Silva Pinto e } \\
\text { de Ivanise Belens Jungmann Pinto. }\end{array}$ \\
\hline $\begin{array}{l}\text { Ricardo } \\
\text { Barros }\end{array}$ & SAÚDE & $\begin{array}{l}\text { Maringá/ } \\
\text { PR } \\
15 / 11 / 19 \\
49\end{array}$ & $\begin{array}{l}\text { - } \\
\text { Engenheir } \\
\text { o Civil, } \\
\text { pela } \\
\text { Universida } \\
\text { de } \\
\text { Estadual } \\
\text { de } \\
\text { Maringá } \\
\text { UEM; } \\
\text { - }\end{array}$ & $\begin{array}{l}\text { - prefeito de Maringá (1989-1993, 1994- } \\
\text { 1998); } \\
\text { - deputado federal (1995-1999, 1999- } \\
\text { 2003, 2003-2007, 2007-2011, 2015- } \\
\text { 2019); }\end{array}$ & $\begin{array}{l}\text { - filho de Silvio Magalhães Barros, } \\
\text { vereador (1961-1964,1965-1966) e } \\
\text { prefeito de Maringá (1971-1973), } \\
\text { além de deputado estadual (1967- } \\
\text { 1970); } \\
\text { - irmão de Silvio Barros, prefeito de } \\
\text { Maringá (2004-2008, 2008-2012); } \\
\text { - marido de Cida Borghetti Barros, } \\
\text { atualmente vice-governadora do } \\
\text { Paraná, deputada estadual (2003- }\end{array}$ \\
\hline
\end{tabular}




\begin{tabular}{|c|c|c|c|c|c|}
\hline & & & $\begin{array}{l}\text { Empresári } \\
\mathrm{o} ;\end{array}$ & & $\begin{array}{l}\text { 2006, 2007-2010) e deputada } \\
\text { federal (2010-2014); } \\
\text { - pai de Maria Victória Borghetti } \\
\text { Barros, deputada estadual no PR } \\
\text { (2014-2018); } \\
\text { - cunhado de Juliano Borghetti, } \\
\text { vereador em Curitiba (2009-2012); }\end{array}$ \\
\hline $\begin{array}{l}\text { Roberto } \\
\text { Freire }\end{array}$ & $\begin{array}{l}\text { CULTUR } \\
\text { A }\end{array}$ & $\begin{array}{l}\text { Recife/P } \\
\text { E } \\
20 / 04 / 19 \\
42\end{array}$ & Direito & $\begin{array}{l}\text { Ingressou no serviço público em 1967, } \\
\text { ao ser aprovado no curso para gerente de } \\
\text { Cooperativa Integral de Reforma } \\
\text { Agrária realizado pelo IBRA. } \\
\text { Posteriormente, assumiu cargo de } \\
\text { procurador autárquico do IBRA - } \\
\text { Instituto Brasileiro de Reforma Agrária } \\
\text { (atual INCRA). É procurador } \\
\text { aposentado do INCRA. Foi deputado } \\
\text { estadual em 1974. Foi eleito para quatro } \\
\text { mandatos sucessivos de deputado } \\
\text { federal. Em 1994 elege-se senador e em } \\
\text { 2002, volta à Câmara para o seu } 5^{\circ} \\
\text { mandato como deputado federal. } \\
\text { Deputado Federal, 1979-1983, PE, } \\
\text { MDB. Dt. Posse: 01/02/1979; Deputado } \\
\text { Federal, 1983-1987, PE, PMDB. Dt. } \\
\text { Posse: 01/02/1983; Deputado Federal } \\
\text { (Constituinte), 1987-1991, 1991-1995, } \\
\text { PE, PCB. Dt. Posse: 01/02/1991; 2003- } \\
\text { 2007, PE, PPS.Deputado Federal, 2011- } \\
\text { 2015, SP, PPS. Dt. Posse: 01/02/2011; } \\
\text { Deputado Federal, 2015-2019, SP, PPS. }\end{array}$ & $\begin{array}{l}\text { Roberto João Pereira Freire foi } \\
\text { casado com Letícia Baltar Freire, } \\
\text { filha do ex-senador Antônio } \\
\text { Bezerra Baltar (1915 - 2003) } \\
\text { Roberto João Pereira Freire é filho } \\
\text { de João de Figueiredo Freire e de } \\
\text { Maria de Lourdes Pereira Freire. } \\
\text { Seu pai era um funcionário de } \\
\text { pequenas empresas privadas } \\
\text { industriais e comerciais na cidade e } \\
\text { a mãe, Maria de Lourdes Pereira } \\
\text { Freire, era dona de casa. }\end{array}$ \\
\hline $\begin{array}{l}\text { Romero } \\
\text { Jucá }\end{array}$ & $\begin{array}{l}\text { PLANEJ } \\
\text { AMENTO }\end{array}$ & $\begin{array}{l}\text { Recife/P } \\
\text { E } \\
30 / 11 / 19 \\
54\end{array}$ & $\begin{array}{l}\text { Economist } \\
\mathrm{a}\end{array}$ & $\begin{array}{l}\text { Em 1984, secretário extraordinário de } \\
\text { Coordenação da Prefeitura do Recife. De } \\
\text { maio de } 1986 \text { a setembro de 1988, } \\
\text { presidiu a Fundação Nacional do Índio } \\
\text { (Funai), indicado por Marco Maciel, no } \\
\text { governo de João Figueiredo. Em 1988, } \\
\text { foi nomeado pelo então presidente José } \\
\text { Sarney e aprovado pelo Senado, } \\
\text { governador do Território Federal de } \\
\text { Roraima. Em 1992, diretor de } \\
\text { Abastecimento da Companhia Nacional } \\
\text { de Abastecimento (Conab) e secretário } \\
\text { nacional de Habitação do Governo } \\
\text { Federal, no Ano que elegeu sua esposa, } \\
\text { à época, Teresa Surita pela primeira vez } \\
\text { prefeita de Boa Vista-RR. Governador- } \\
\text { RR (1988-1990) Senador - RR } \\
\text { (1995-2003//2011// 2011- } \\
\text { 2016// 2016-2024). Ministro da } \\
\text { Previdência Social Governo Lula. }\end{array}$ & $\begin{array}{l}\text { Romero Jucá (PMDB), ex-marido } \\
\text { da prefeita de Boa Vista (RR), a } \\
\text { ex-deputada federal e atual prefeita } \\
\text { de Boa Vista, Teresa Surita } \\
\text { (PMDB-RR). Teresa Surita é irmã } \\
\text { do apresentador de televisão Emílio } \\
\text { Surita. Ele é dono do maior grupo } \\
\text { de comunicação do estado de } \\
\text { Roraima sendo duas emissoras de } \\
\text { televisão na capital Boa Vista } \\
\text { afiliadas da Rede Record, TV } \\
\text { Imperial, e afiliadas da Rede } \\
\text { Bandeirantes além de um jornal } \\
\text { impresso e duas estações de rádio. } \\
\text { Romero Jucá é pai do deputado } \\
\text { estadual Rodrigo Jucá (PMDB-RR). }\end{array}$ \\
\hline $\begin{array}{l}\text { Ronaldo } \\
\text { Nogueira } \\
\text { de } \\
\text { Oliveira }\end{array}$ & $\begin{array}{l}\text { TRABAL } \\
\text { HO E } \\
\text { PREVIDE } \\
\text { NCIA } \\
\text { SOCIAL }\end{array}$ & $\begin{array}{l}\text { Carazinh } \\
\text { o/RS } \\
25 / 04 / 19 \\
66\end{array}$ & $\begin{array}{l}\text { Administra } \\
\text { ção de } \\
\text { empresas }\end{array}$ & $\begin{array}{l}\text { Vereador em Carazinho/RS em } 4 \\
\text { mandatos consecutivos (1992 a 2007). } \\
\text { Secretário Municipal de Habitação e } \\
\text { Assistência Social de Carazinho/RS } \\
\text { (1997-1998). Secretário Municipal de } \\
\text { Obras e Serviços Urbanos Carazinho/RS } \\
\text { (2003-2004). Diretor do Departamento } \\
\text { de Transportes da governadora Yeda } \\
\text { Crucius/RS (2007-2008). Diretor- } \\
\text { presidente da Fundação Gaúcha de }\end{array}$ & $\begin{array}{l}\text { Ronaldo Nogueira (PTB) é pastor } \\
\text { evangélico da Assembleia de Deus. } \\
\text { Faz parte da bancada evangélica. } \\
\text { Filho de Cecília Nogueira de } \\
\text { Oliveira. Miriam Nogueira de } \\
\text { Oliveira é sua filha. A indicação do } \\
\text { deputado federal Ronaldo Nogueira } \\
\text { (PTB-RS) para o Ministério do } \\
\text { Trabalho, Michel Temer abriu vaga } \\
\text { para o suplente Cajar Nardes (PR- }\end{array}$ \\
\hline
\end{tabular}




\begin{tabular}{|c|c|c|c|c|c|}
\hline & & & & $\begin{array}{l}\text { Trabalho e Ação Social da governadora } \\
\text { Yeda Crucius/RS (2008-2010). } \\
\text { Deputado suplente federal/RS pelo PTB } \\
\text { (2011-2014) - assume no lugar de Luiz } \\
\text { Carlos Busato. Deputado federal/RS } \\
\text { pelo PTB (2015-2018). }\end{array}$ & $\begin{array}{l}\text { RS), irmão do ministro do Tribunal } \\
\text { de Contas da União, Carlos } \\
\text { Augusto Nardes, relator do } \\
\text { processo de contas do governo } \\
\text { Dilma Rousseff, em 2014. }\end{array}$ \\
\hline $\begin{array}{l}\text { Sérgio } \\
\text { Etchegoyh } \\
\text { en }\end{array}$ & $\begin{array}{l}\text { GABINE } \\
\text { TE DE } \\
\text { SEGURA } \\
\text { NÇA } \\
\text { INSTITU } \\
\text { CIONAL }\end{array}$ & $\begin{array}{l}\text { Nasceu } \\
\text { na } \\
\text { cidade } \\
\text { de Cruz } \\
\text { Alta RS } \\
1 / 2 / 52\end{array}$ & $\begin{array}{l}\text { General do } \\
\text { Exército } \\
\text { Brasileiro }\end{array}$ & $\begin{array}{l}\text { Ingressou no Exército Brasileiro em } 1^{\circ} \\
\text { de março de 1971, na Academia Militar } \\
\text { das Agulhas Negras, sendo declarado } \\
\text { Aspirante a Oficial de Cavalaria em } 17 \\
\text { de dezembro de } 1974^{21} \text {. }\end{array}$ & $\begin{array}{l}\text { Sérgio Westphalen Etchegoyen - } \\
\text { Filho do General de Brigada Leo } \\
\text { Guedes Etchegoyen e de Lucia } \\
\text { Westphalen Etchegoyen.Família de } \\
\text { militares. }\end{array}$ \\
\hline $\begin{array}{l}\text { Wellington } \\
\text { Moreira } \\
\text { Franco }\end{array}$ & $\begin{array}{l}\text { SECRET } \\
\text { ARIA } \\
\text { ESPECIA } \\
\text { L DE } \\
\text { INVESTI } \\
\text { MENTO }\end{array}$ & $\begin{array}{l}\text { Nasceu } \\
\text { em } \\
\text { Teresina } \\
\text {-PI, em } \\
1944 .\end{array}$ & Sociólogo & $\begin{array}{l}\text { Ingressou na política em 1974, quando } \\
\text { elegeu-se deputado federal pelo estado } \\
\text { do Rio de Janeiro, na legenda do } \\
\text { Movimento Democrático Brasileiro } \\
\text { (MDB). Dois anos depois, ganhou as } \\
\text { eleições para prefeito de Niterói. Em } 15 \\
\text { de março de 1987, tomou posse como } \\
\text { governador do Rio de Janeiro"22. }\end{array}$ & $\begin{array}{l}\text { "Wellington Moreira Franco } \\
\text { conhecido como "genro do genro" } \\
\text { foi casado com Celina Vargas do } \\
\text { Amaral Peixoto, filha de Ernani do } \\
\text { Amaral Peixoto e Alzira Vargas, a } \\
\text { filha de Getúlio Vargas. Wellington } \\
\text { teve o irmão Nelson Moreira } \\
\text { Franco, ex-Secretário de } \\
\text { Desenvolvimento Social do Estado }\end{array}$ \\
\hline
\end{tabular}

Elaboração dos autores

\section{Considerações finais}

Observamos que os dois coletivos analisados, o dos "Operadores da Lava-Jato" e o "Ministério Temer" apresentam as mesmas estruturas prosopográficas, a mesma centralidade na hereditariedade, reprodução de capitais sociais familiares, escolarização de elite, trajetórias dentro da elite estatal, relações familiares e políticas decisivas para as carreiras da grande maioria dos atores pesquisados em suas biografias, cargos e itinerários ideológicos tradicionais, preferencialmente à direita política e conservadores. $\mathrm{O}$ núcleo duro da Lava-Jato é formado por operadores vinculados à famílias políticas e famílias do sistema judicial (Rodrigo Janot Monteiro de Barros, Sérgio Moro, Carlos Fernando dos Santos Lima, Deltan Dallagnol, Diogo Castor de Mattos). Dos 31 ministros listados, 17 apresentaram significativos capitais sociais e políticos

21 Disponível em http://www.gsi.gov.br/ministro/biografia e http://politica.estadao.com.br/noticias/geral,cenario-umafamilia-ligada-aos-levantes-nos-quarteis-ha-90-anos-imp-,1605865. Ambos os sítios acessados 18.junho.2017.

22 Disponível em http://www2.planalto.gov.br/presidencia/ministros/secretaria-geral-da-presidencia-da-republica. Acesso 18.junho.2017. 
familiares nas suas trajetórias (Torquato Jardim, Aloysio Nunes, Bruno Araújo, Fernando Coelho Filho, Geddel Vieira Lima, Helder Barbalho, Henrique Alves, Henrique Meirelles, Mendonça Filho, Sarney Filho, Leonardo Picciani, Maurício Lessa, Ricardo Barros, Roberto Freire, Jucá, Etchegoyen e Moreira Franco). Mesmo os nomes que não possuíam forte influência familiar, como o caso de Ronaldo Nogueira, sofrem a constante influência das redes familiares, como no interesse da posse do seu suplente Cajar Nardes (PR-RS), irmão do ministro do Tribunal de Contas da União, Carlos Augusto Nardes, relator do processo de contas do governo Dilma Rousseff, em 2014. Os principais operadores da Lava-Jato e boa parte dos Ministros de Temer não são membros da "classe média", ou apenas técnicos e gestores, quase todos são membros, ou casaram, com importantes famílias políticas presentes ao longo da história nos poderes executivo, legislativo e judiciário. Todos os nomes aqui listados pertencem ao $1 \%$ mais rico, quando não ao $0,1 \%$ mais rico e sempre revelam a característica "familiar" do sistema judicial e do governo no Brasil, presentes em todas as suas regiões. Os padrões de "moralidade"podem ser observados quando operadores, como o agente da Polícia Federal Newton Hidenori Ishii, vulgo “Japa da Federal”, revelam quase sempre possuírem uma verdadeira história oculta de malfeitos por detrás das imagens e discursos da mídia oficial, como "heróis salvadores da República". A oposição, a crítica e mesmo valores como o "ódio" social e político à democracia, às eleições, aos movimentos sociais e sindicais, ao Partido dos Trabalhadores, à Central Única dos Trabalhadores, bem como aos discursos da esquerda representam outra característica bastante frequente dessas formas de "lawfare". Muitos desses atores participaram, apoiaram pessoalmente e tiveram familiares participando de manifestações contra os presidentes Lula, Dilma e os governos do PT. O resultado é um governo golpista. Quase todos os investigados possuem bons vínculos e boas relações com a mídia hegemônica, muitos participando ativamente de programas e eventos juntos aos principais veículos da mídia dominante do Brasil. Formam todos grandes redes de sociabilidade e interação, como solenidades e eventos privados e oficiais em que se encontram, celebram e compartilham os mesmos valores, mentalidades, ideologias e cultura política, de modo que reproduzem geração a geração as mesmas estruturas familiares dentro das instituições estatais e das empresas privadas, casando com pessoas com perfis sociais, culturais e ideológicos semelhantes. O clube fechado pode ser verificado em eventos como o Grupo de Líderes Empresariais - LIDE, do Prefeito João Doria, de São Paulo. Este texto de debate reafirma a teoria do nepotismo desenvolvida pelo grupo de pesquisadores. A política e a justiça no Brasil continuam sendo em boa parte negócios de família. 


\section{Referências}

ALMEIDA, Frederico Normanha Ribeiro de (2010). A nobreza togada: as elites jurídicas e a política da Justiça no Brasil. Tese de Doutorado em Ciência Política. Universidade de São Paulo. 2010. Disponível

Macedo, João Noel Azevedo \& Macedo, Enólia Bacellar (1998). Genealogia de Manoel Ribeiro de Macedo. Curitiba: Edição dos Autores.

PALUDO, Januário (2011). Forças-tarefas: direito comparado e legislação aplicável. Brasília: MPF, 15.junho.2017.

STONE, Lawrence (2011). Prosopografia. Revista de Sociologia e Política, Curitiba, v.19, n. 39, p. 115-137, junho.

Fontes para elaboração dos quadros:

http://cpdoc.fgv.br/

https://www.congressonacional.leg.br/portal/

http://www.mdic.gov.br/institucional/o-ministro

http://www2.camara.leg.br/

http://www12.senado.leg.br/

http://www.stf.jus.br/

http://www2.planalto.gov.br/

http://www.arquivonacional.gov.br/

http://memoria.bn.br/hdb/periodico.aspx 